OECD Working Papers on Fiscal Federalism No. 06

\title{
Market mechanisms \\ in public service provision
}

\section{Hansjörg Blöchliger}

https://dx.doi.org/10.1787/4c56c441-en 
OECD Network on Fiscal Relations Across Levels of Government

MARKET MECHANISMS IN PUBLIC SERVICE PROVISION

Working Paper $\mathrm{N}^{\circ} 6$

Hansjörg Blöchliger, Economics Department, O.E.C.D. 


\section{TABLE OF CONTENTS}

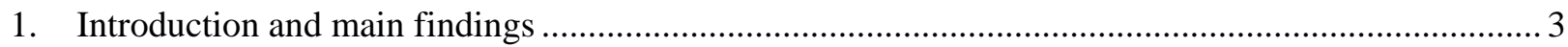

2. Market mechanisms: definition, measurement and scope............................................................. 5

2.1. What is a "market mechanism"? ............................................................................................... 5

2.2. Measuring the use of market mechanisms: institutional indicators .............................................. 5

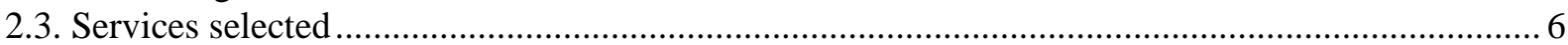

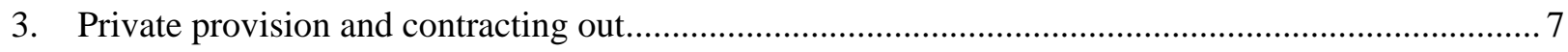

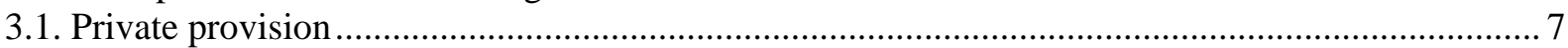

3.2. Tendering, outsourcing, and public-private partnerships ......................................................... 8

3.3. Results for the intermediate institutional indicator "private provision and contracting out" ......... 10

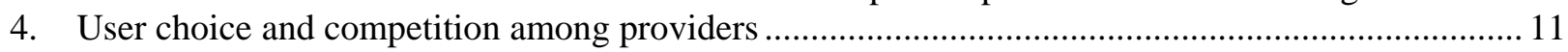

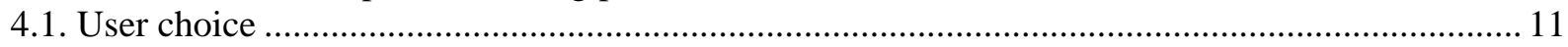

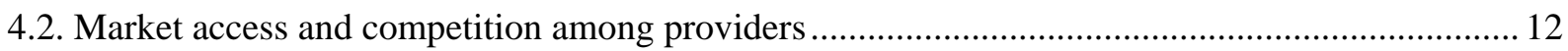

4.3. Results for the intermediate indicator "user choice and competition among providers"................. 13

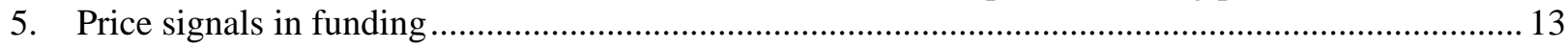

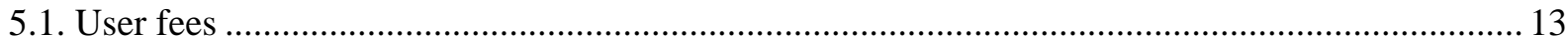

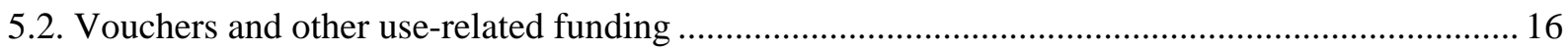

5.3. Results for the intermediate indicator 3 "price signals in funding” "............................................ 16

6. Summary indicator of the use of market mechanisms and the policy reform gap ............................. 17

6.1. Summary indicator: market mechanisms in public service provision ............................................17

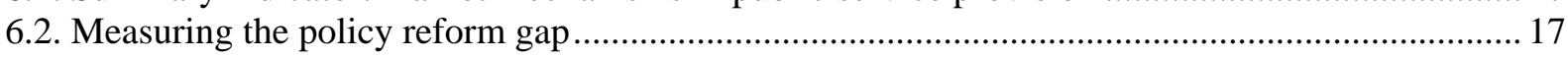

7. Trade-offs and side effects of market mechanisms in public service provision................................. 18

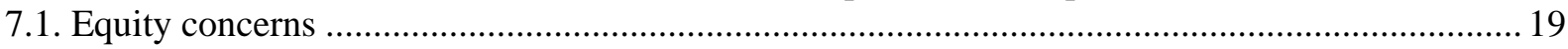

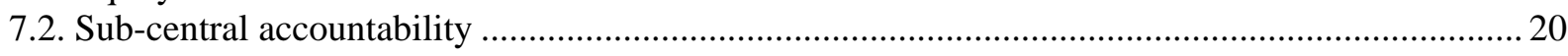

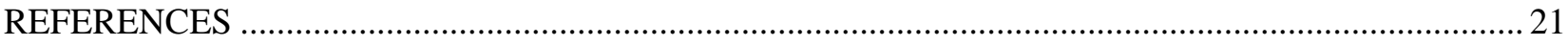

Annex: Constructing a summary indicator of market mechanism reliance 37

\section{Boxes}

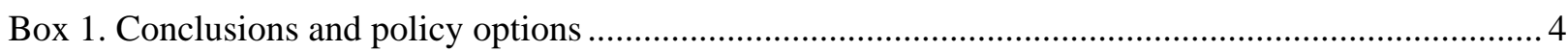

Box 2. Private provision and contracting out in public transport: a snapshot of OECD countries ............. 9

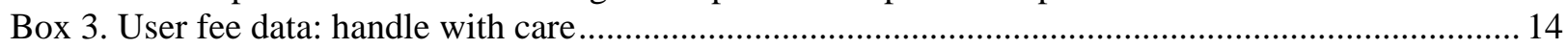

Box 4. Differentiating user fees between residents and non-residents ..................................................... 15 
COM/CTPA/ECO/GOV/WP(2008)6

\section{MARKET MECHANISMS IN SUB-CENTRAL PUBLIC SERVICE PROVISION}

\section{Introduction and main findings}

1. This paper compares and analyses the use of market mechanisms in core sub-central policy areas, namely education, health care, transport, social protection, and environment. Arrangements like tendering, outsourcing, user choice and competition, user fees and performance-related funding can help to improve quality of service provision or lower its cost. With around $32 \%$ of total public expenditure and often wide-ranging spending powers, sub-central governments (SCG) have considerable leeway for improving their services by relying on market mechanisms. The decentralised and often fragmented nature of sub-central government poses some special challenges to efficient arrangements, however, and may require central government support or stronger inter-jurisdictional co-operation. And while market mechanisms are being harnessed ever more broadly, limits to a more extensive use have become apparent, particularly in the potential trade-off between greater efficiency and equity objectives, or between efficiency and sub-central accountability.

2. The paper is organised as follows. This section gives the main findings and draws some policy implications. The second section describes the properties of "market mechanisms", develops a framework of institutional indicators for measuring their use, and presents the public services selected for the market mechanism test. The third to fifth sections describe, for the various market mechanisms under study, both the policy issues involved and the extent to which sub-central governments rely on those mechanisms, as portrayed by a set of institutional indicators. The sixth section presents a comparative summary indicator portraying the use of market arrangements in OECD countries and the policy reform gap for the selected sub-central services. The seventh section deals with potential trade-offs and side effects on equity and sub-central accountability.

3. The main findings can be summarised as follows:

- Sub-central governments are sometimes hesitant to apply market mechanisms: SCGs make use of market-like arrangements to a varying extent and for most services, regulatory innovations like private provision, competitive tendering and user choice have become more common than financial innovations like user fees and voucher-like funding arrangements.

- Sub-central technical services are closer to the market than social services: In technical services like public transport or waste collection market arrangements such as tendering, competition or user fee funding are quite advanced. In social services like education, health, or childcare market arrangements such as user choice, private provision or performancerelated funding is less common.

- Sub-central out-contracting is hampered by a fragmented regulatory framework. Tendering, outsourcing and public-private partnerships have become quite common at the sub-central level, particularly for technical services. However, efficiency of outcomes is sometimes reduced by non-harmonised regulation across levels of government and the absence of interjurisdictional co-ordination. 
- User choice is often limited: Sub-central governments considerably restrict user choice in compulsory education and a little less for hospitals, childcare and nursing homes. Giving more choice to consumers can increase providers' responsiveness but may require the setup of inter-governmental funding arrangements.

- Sub-central governments rely little on user fees and performance-related funding: Most user fees accrue to the sub-central level, but usually cover only a small part of total cost. Also performance-related funding - like vouchers and other use-based funding - is not very frequent. Enhancing their use may also require intergovernmental funding arrangements.

- Equity is an important concern: Market mechanisms may jeopardise equal and universal access to public services. To promote equal access, most governments have put minimum standards in place, but also measures like service obligations, means-tested income support, user fee differentiation, voucher systems or specific grants to providers.

- Central regulation may reduce sub-central autonomy. Central regulation on market mechanism implementation or on service standards can reduce sub-central service accountability. Framework legislation -- leaving SCGs more room for flexible adaptation -and fiscal equalisation -- which allows but does not compel SCGs to reach national standards -- can reduce this trade-off.

4. The analysis shows that there is a substantial scope for increasing the efficiency of public service delivery through market mechanisms, but also suggests important impediments in doing so. The main policy implications, for both central and sub-central governments, are described in Box 1.

\section{Box 1. Conclusions and policy options}

Relying on policy evaluation and indicators portraying their current use, the paper shows how and where market mechanisms could increase efficiency of public service delivery, suggesting the following policy options for both central and sub-central government:

- $\quad$ Contracting out: by relying more on open tenders, governments are likely to obtain public service delivery at lower cost. In order to avoid fragmented markets detrimental to efficiency, tendering rules should be harmonised across jurisdictions and government levels and central or sub-central governments may set up specialised agencies to deal with contracting out.

- Granting user choice: user choice is likely to increase responsiveness of service providers. Mechanisms whereby money follows the user ("vouchers") can strengthen this effect. To be viable across jurisdictions, user choice and voucher systems must be introduced together with horizontal financial agreements or central government compensation.

- $\quad$ Relying more strongly on user fees: user fees may accommodate excessive demand as well as raise revenue in order to increase public service quality. User fees should be closely related to public service cost, in order not to become a form of hidden taxation.

- $\quad$ Promoting equal access: increasing the use of market mechanism can -- but need not -- have undesirable distributional effects, both in social or geographical terms. Both central and sub-central government may have to introduce explicit minimum standards regarding service coverage, introduce means-tested income support or grant subsidies to service providers. Governments may also have to ensure that providers are not allowed to turn users away.

- Maintaining sub-central autonomy: centrally-established rules may have to ensure efficient implementation of market mechanisms. To reduce the trade-off between central regulation and sub-central service accountability, central government may enact framework legislation, leaving more flexibility to SCGs. Also fiscal equalisation can help SCGs reach national standards but does not compel them to do so. 
5. Most information in this paper draws on a questionnaire sent to Member countries of the Fiscal Federalism Network in April 2007 to which 17 countries had answered fully or partially. Additional information was drawn from work on public spending efficiency by the Economics Department of the OECD, from OECD National Accounts, and from OECD education and health care databases.

\section{Market mechanisms: definition, measurement and scope}

\subsection{What is a "market mechanism"?}

6. The term "market mechanism", as it is used here, covers the set of rules and institutions of a market economy as applied to the public sector. On the supply side, they embrace arrangements such as tendering, outsourcing and private provision. On the demand side, they include instruments such as user choice, "vouchers" and other forms of use- and performance-related funding. Many sub-central public services are potentially open to competition among providers, and by separating provision from funding SCGs can retain the essential properties of a public service while reaping the benefits of market mimicking. Market mechanisms can increase the efficiency of public service delivery in three distinct ways. They can improve productive efficiency by raising the quality and lowering the cost of providing publicly-funded services. They can increase welfare by making public providers more responsive to consumers' tastes and preferences, thus improving resource allocation. And they can improve budget management efficiency through enhanced awareness of the resource costs of providing services.

7. The set of market mechanisms can be grouped under three headings, each reflecting the properties of a market economy, namely $i$ ) private ownership and contracting, ii choice and competition, and iii) price signals (adapted from Kahn, 1988 and Frey, 2004). Applied to public service provision, the three headings subsume the following mechanisms:

1. Private ownership and contracting out: this group deals with public and private ownership and different forms of contracting such as tendering, outsourcing, public-private partnerships and others.

2. User choice and competition: this group deals with the regulatory environment for public service providers; the extent to which consumers are allowed to choose among providers and to what extent providers have access to the market.

3. Price signals in funding: this group deals with the principles of funding public service provision; the extent to which user fees are charged, and the extent to which public funding reflects actual service utilisation and/or service performance.

8. In combination, the three groups should cover all potential market arrangements in service delivery, from a public monopoly funded through general taxes up to competing private providers funded by user fees. Each market mechanism group will be discussed in more detail in sections 3 to 5 .

\subsection{Measuring the use of market mechanisms: institutional indicators}

9. Throughout this paper, the use of market mechanisms at SCG level will be measured by means of a set of institutional indicators. Institutional indicators assess a country's policy arrangements in quantitative terms and based on an economic evaluation. Applied to the present case, they evaluate the extent to which SCGs harness the three market mechanism dimensions when providing public services, and whether they harness them efficiently. Institutional indicators are hence a normative construct: they describe the arrangements which are supposed to have a positive impact on public service efficiency. Once service output measures are available, empirical analysis could link 
them to the institutional indicators and help identify those arrangements most likely to promote efficiency. ${ }^{1}$

10. The indicator set is shown as an "indicator tree" with low-level indicators (LLI), intermediate indicators (ILI) and the summary indicator (SI) (Figure 1). Indicator values draw on responses to the 2007 Network questionnaire. Indicator construction starts with a series of 15 LLIs that describe one specific market mechanism aspect. Indicator values are scaled between 0 and 10 , with a higher value associated with a more favourable arrangement. LLIs are then aggregated to form three ILIs reflecting the three market mechanism groups -- (a) private provision and contracting out, (b) user choice and competition, (c) price signals in funding -- described above. The three ILIs are finally aggregated to yield a single summary indicator portraying the use of market arrangements in public service provision. Indicator selection and results will be presented in more detail in the appropriate sections. Details on coding and aggregation across services, SCG levels and indicators, in order to obtain the summary indicator, are explained in the Annex.

11. Particular weight is given to the consistency of market arrangements. The policy background for doing so is that market mechanisms are supposed to be more efficient if applied as a coordinated package rather than as isolated measures. Consistency is accounted for in several ways: first, by inserting specific "consistency indicators", second, by applying the random weights technique when aggregating indicators, and, third, by applying both additive and multiplicative aggregation to intermediate indicators in order to obtain the summary indicator. Consistency across services is however not assessed, assuming that low or inefficient implementation of market mechanisms in one service (e.g. public transport) does not affect the efficiency outcome in another (e.g. nursing homes). A more detailed description of the procedures to reflect consistency is provided in the Annex.

\section{[Figure 1. Market mechanisms in public service provision: indicator tree]}

\subsection{Services selected}

12. When selecting public services for the market mechanism test, it is useful to recap on the level, evolution and functional division of SCG expenditure. Sub-central governments account for $32 \%$ of total government expenditure on average, with the share having increased by 3 percentage points in the past ten years (Figures 2 and 3). Cross-country variation is, however, large. In more than two thirds of countries the sub-central spending share rose. In almost every country for which data for two sub-central levels are available both the local and the state level moved in parallel.

\section{[Figure 2. Decentralisation of public spending, 2005]}

\section{[Figure 3. Decentralisation of public spending, evolution 1995-2005]}

13. Figure 4, which is divided into a section for federal/regional countries and unitary countries, shows the main policy areas on which SCGs spend money (for a closer analysis see Table A4 in the Annex $)^{2}$. Accounting for around a quarter of SCG expenditure, education is by far the most important item, followed by social security and welfare, economic affairs, health care, and finally environmental protection. The "other" category which plays a more important role in federal than in unitary countries includes different neighbourhood services such as culture, sports and recreation. Again cross-country variation in spending assignment is large, but in most countries education, economic

1. Such empirical analysis was performed for primary and secondary education, where a set of institutional indicators in the education sectors was regressed on educational outcomes drawn from the PISA studies (Sutherland and Price, 2007)

2. Policy areas are classified according to the National Accounts Classification of Functions of Government (COFOG-1). 
affairs, health care, social protection and environment put together make up roughly 65 to $75 \%$ of total SCG spending.

\section{[Figure 4. Sub-central spending by functions]}

14. Based on Figure 4, Delegates of the Statistical Working Group meeting in February 2008 selected a set of sub-central services for the market mechanism test (Table 1). Those services embrace a wide spectrum of sub-central policy areas and are thought to constitute major sub-central expenditure items. ${ }^{3}$ A number of traditional SCG services where market mechanisms are widely applied were left out, e.g. network industries such as electricity or water provision. This might be unfortunate but can be justified since the objective of this activity is to analyse services for which public spending is significant. ${ }^{4}$ Actually, if all market mechanisms were applied to a public service, the latter would disappear from the government financial accounts.

\section{[Table 1. Public services covered]}

\section{Private provision and contracting out}

15. This section deals with the first branch of the market mechanism indicator tree shown in Figure 1. It first deals with policy issues related to private provision, tendering, outsourcing and public-private-partnerships in the provision of public services and then presents the results of the institutional indicators measuring the extent to which countries rely on private providers and contracting arrangements when providing services.

\subsection{Private provision}

16. Private provision means service production by companies, cooperatives, foundations, consumer associations and other non-governmental organisations. Most meta-studies evaluating SCG services acknowledge that privatisation increases productivity, although they often mention that the effect is stronger in the short than in the long run and that competition among providers is a much stronger drive than private provision itself (e.g. for technical services Jensen and Stonecash, 2004). The productivity gains from private provision are likely to root in more flexible production processes. Private providers tend to operate under less rigid organisational rules, to have more flexible labour relations, to be more innovative and are more likely to adapt services to consumer demand (Farsi and Filippini 2004). In order to avoid that profit-seeking can mitigate the search for better quality or lower cost -- particularly if competition among providers is limited -- many SCGs permit market access to private non-profit organisations only.

17. All countries rely at least partly on private providers when supplying public services (Table 2). Australia, the Netherlands and Belgium do so more than Turkey, Greece or the Slovak Republic. Private provision is more common in technical services such as public transport and waste collection than in social services such as hospitals, childcare and nursing homes where principal-agent problems -- such as the definition and supervision of quality standards -- may arise. Although primary and secondary education is the largest single sub-central budget item, here private provision plays little or no role at all; moreover in some countries private schools cannot obtain any funding from government. Tertiary education is more varied, with many private providers offering university and

3. Expenditure data at the service level (COFOG-2) are however not yet available The COFOG-2 classification covers around 60 to 70 services. COFOG-2 is in a preliminary stage and currently tested by a European Union task force.

4. Sweden stated that it did not fill in the questionnaire for "waste collection and disposal" as this service was almost entirely fee-funded and representing a tiny portion of SCG expenditure only. 
vocational training in advanced studies. Variation across countries is large and the pattern seems to be partly determined by historical coincidence rather than policy choice.

\section{[Table 2. Share of public services provided by private providers]}

\subsection{Tendering, outsourcing, and public-private partnerships}

18. The term "contracting out" covers a set of contractual arrangements between the public and the private sector. Arrangements may vary, but usually three forms of out-contracting are distinguished:

- Tendering: Tendering provides a way to introduce competition to sub-central public service provision whilst preserving integrated networks. Such services are often characterized by network externalities, strong economies of scale and scope, and low marginal and high sunk costs, making them prone to monopolistic behaviour. Tendering introduces "competition for the market", thereby reducing the trade-off between obtaining efficiency through competition and obtaining efficiency through network economies. ${ }^{5}$ At the sub-central level, tendering is most common for technical services like public transport (see Box 2) but in some countries is also applied to social services. ${ }^{6}$ Tendering allowed a typical cost savings of around $20 \%$ in public transport and waste collection (e.g. Bekken et al., 2006). Tendering is more common in smaller municipalities and regions than in metropolitan areas (Dijkgraaf et al., 2003).

5. Tendering rules can either foster network integration or competition between network providers. While Continental European and, to some extent, Japanese arrangements tend to favour integrated local networks and the efficiencies resulting thereof, arrangements in the United States tend to favour competition among network providers (Warner and Bel, 2006).

${ }^{6}$. $\quad$ In some countries provision of elderly care is tendered to private firms and non-profit organisations (Lundsgaard, 2002) 
Box 2. Private provision and contracting out in public transport: a snapshot of OECD countries

Starting in the mid-'90s, OECD countries have considerably reformed the regulatory framework in local and regional public transportation services. Transport companies were privatised, tendering became common, and markets were opened to new providers, resulting in productivity gains and improvements in service levels. Most countries have different regulatory frameworks for local/regional and for national public transport services, and the market for local and regional transport services today is in many countries more open to competitive forces than national, long-distance public transport, often provided by a monopolistic state-run railway company.

Market openness is most advanced in inter-regional bus transport. Bus companies often work on a commercial basis, are free to enter the market and to offer whichever scheduled service they deem profitable, but usually need a concession. Bus services in sparsely populated areas are in general tendered, with the winning bid going to the company asking for the lowest subsidy to run the service (reverse bidding). In large metropolitan areas transport services are usually overseen by a public transport authority organising the different transport modes (trains, metros, trams, buses) and acting as a one-stop-shop for users. Here tendering is less common and services are often provided by a public company, with bus services more open to the market than railways. Some private or sub-centrally government-owned railway companies operate on their own tracks or on the network of a national provider, but private providers offering intra-urban or suburban rail services on an open access basis remain the exception rather than the rule. In middle-sized cities where transport networks are less complex, where externalities between national and sub-national network utilization are smaller and where transport relies largely on buses, tendering has become quite frequent. In most cases, tenders are offered for entire networks rather than single lines, and the tendering period is for 5 to 8 years.

Regulatory reforms in sub-central public transport services have not advanced evenly, however. Around half of OECD countries require sub-central governments to open sub-central public transport services to competition, generally in the form of tendering. The European Union exerts some pressure through their internal market programme but sector-specific legislation has not yet passed. Many countries are still in a transition period where some jurisdictions have opened their markets while others have not or for parts of their networks only. Moreover, sub-central governments where transport services are produced "in-house", i.e. through a government agency instead of an autonomous (public or private) company, are not required to tender. Tendering rules are often skewed towards public providers (e.g. private firms have to pay taxes while public agencies do not), and only a few countries require strict policy neutrality between private and public providers. Inter-regional bus services are severely restricted or forbidden outright in many countries in order to shelter railway companies from competition.

Further reforms of the sub-central public transport regulatory framework concentrate on metropolitan areas where competitive tendering is slowly becoming more common. Also, railway reforms can open up one of the backbones of metropolitan public transport and reduce the gap between a highly restricted rail sector and a more open bus sector. Applying uniform market arrangements across jurisdictions, levels of government and transport modes could allow for more coherent and efficient public transport networks.

Source: Questionnaire responses provided by Finland, the Netherlands, Italy, Japan, Sweden, Switzerland; OECD, 2006 and OECD, 2007.

- Outsourcing: Outsourcing is the transfer of support functions to an external organisation. Outsourcing is different from tendering since the core service -- such as teaching in a school or medical care in hospitals -- remains within the public provider, but outsourcing procedures are otherwise quite similar to tendering. According to questionnaire responses, support functions typically outsourced include cleaning, security, catering (schools, hospitals, nursing homes, childcare), maintenance (transport, waste collection), and in some cases IT services. Taking all government levels and functions together, outsourcing accounts for 10 to $20 \%$ of value added, with education and health care located at the lower end (Lundsgaard, 2002). In general sub-central governments are free to decide what functions to outsource, except for core functions in education and health care where central government often sets limits. 
Public-Private Partnerships: The term Public-Private Partnerships (PPP) embraces infrastructure projects whose design, funding, construction and, sometimes, operation is conferred to a private provider. In turn, the private provider receives an annual subsidy for a fixed time. PPPs have become popular since they not only tend to increase allocative efficiency but allow sub-central governments to spread spending more evenly over an investment's life span. Most PPPs are contracted at the sub-central level. In Germany, around $80 \%$ of PPP-investment is spent at the Länder and municipal level, making up 2 to 3\% of SCG investment (Deutsches Institut für Urbanistik, 2005), while in France, more than 50\% of PPPs are arranged at the sub-central level (Institut de la Gestion Déléguée, 2006). With the "Private Finance Initiative" the United Kingdom has the most advanced PPPs covering around 200 projects totalling £26 billion and representing 10 to $15 \%$ of total public service investment, mostly administered by local governments (UK Treasury, 2007).

19. Sub-central governments have to weigh the advantages of contracting out against some pitfalls. ${ }^{7}$ SCGs often find it difficult to specify contracts, to assess the risks associated with long-term projects and to distribute them fairly between the private and the public sector. Contractual agreements can unduly play in favour of the private sector as sub-central jurisdictions negotiate with experienced private contractors, often operating internationally. While some central governments have set up specialised agencies to deal with private sector involvement in out-contracting projects (Australia, Ireland, the United Kingdom), sub-central governments have less access to specialised knowledge. Stronger inter-municipal cooperation and information exchange could reduce asymmetries and build up the capacities to deal with privately financed projects. Moreover, some funding arrangements -- PPPs in particular -- shift financial obligations to the future and may serve to bypass self-established or central-government-imposed fiscal rules (Sutherland, et al., 2005). Outcontracting may also reduce sub-central budget accountability, particularly if it is financed through off-budget operations.

20. Jurisdictional fragmentation is a salient obstacle, for both governments and providers, to achieving satisfactory contracting results, particularly for network services. In many countries, individual jurisdictions are too small to allow providers to reach sufficient economies of scale and specialisation, and varying contracting rules and timings make it hard for operators to offer optimal network sizes across jurisdictional borders. Since sub-central governments sometimes prefer "their" local incumbent over an outside provider, there are often as many different operators as there are jurisdictions. Constrained by jurisdictional fragmentation, Italian local and regional bus services appear to run below optimal density (Cambrini and Filippini, 2003), and most Swiss utilities such as railways or electricity distributors are clearly undersized (Waldmann, 2003). ${ }^{8}$ Harmonising tendering rules across jurisdictions and government levels can help overcome those inefficiencies, and intergovernmental co-operation may allow a build up of specialised knowledge in contracting. In European countries sub-central tendering is increasingly subject to EU internal market regulations trying to enforce uniform tendering rules.

\subsection{Results for the intermediate institutional indicator "private provision and contracting out"}

21. As described in earlier sections of this paper, the use of market mechanisms in public service provision will be measured using a set of institutional indicators. The extent to which SCGs

7. An assessment of the pros and cons of PPPs at both the central and sub-central level in Germany can be found in OECD (2006). For the United Kingdom, Shaoul (2005) and Allen (2001).

8. Jurisdictions may also be too large for a single network and a division into several networks may be more efficient. Some large cities tender bus services along urban districts and even on a line-by-line basis (Toner, 2002), although empirical evidence suggests that network services should be tendered as such (e.g. Karlaftis and MacCarthy, 2002). 
rely on private provision and contracting out is measured by intermediate-level indicator 1 "private provision and contracting out". This indicator is based on five low-level indicators (LLIs), assessing, respectively, the percentage of private providers (LLI-1), the extent of outsourcing (LLI-2), the extent of tendering (LLI-3), whether private providers can obtain government funding (LLI-4), and central government's role in supporting private provision at SCG level (LLI-5). All information contained in the LLIs is described in the policy parts of this section. Coding for LLIs to obtain the intermediate indicator is shown in Table A1 in the Annex.

22. Numerical results for intermediate indicator 1 show high values for Sweden, Australia and Belgium (Flemish part) and low values for Italy, Switzerland and Mexico (Figure 5). Confidence intervals -- shown by the vertical bar through each indicator value -- are particularly low in Australia, pointing at consistent private provision and out-contracting arrangements there. Variation of LLIs across countries is lower than variation across services (not shown in the figure), which can be explained by some "compensation across services", e.g. Switzerland scores very low (= few private providers and little contracting out) in education and quite low in local and regional public transport but it scores higher in childcare and elderly homes, while the inverse is true for Sweden and Finland. Almost every country boasts few services with strong market profile that compensate for services with weak market profile, resulting in relatively small cross-country variation for the intermediate indicator. As a corollary, while an indicator covering all services can give a synoptic view of market mechanism reliance in a country, a closer look at each service is needed for deeper policy analysis.

\section{[Figure 5. Intermediate level indicator 1: private ownership and contracting out]}

\section{User choice and competition among providers}

23. This section deals with the second branch of the market mechanism indicator tree shown in Figure 1 "user choice and competition among providers". It first deals with policy issues related to user choice and provider competition in service provision and then presents the questionnaire results in terms of the institutional indicators measuring the extent to which countries grant user choice and allow for competition among providers.

\subsection{User choice}

24. User choice means the right of an individual consumer to choose among several service providers, such as schools, hospitals, nursing homes, or waste collectors. User choice is meant to improve providers' responsiveness to consumers' tastes and preferences. If consumers can experience and compare service output across providers, user choice is likely to increase welfare and to improve service quality, particularly if several service providers are at "reasonable" distance from the user's residence. ${ }^{9}$ User choice could also have negative consequences, particularly if providers in turn are also allowed to select users. Selection may lead to filtering and segregation of different groups of users, and it may raise equity concerns. The advantages and limits of user choice are treated in earlier OECD publications (e.g. Lundsgaard 2002 or Joumard et al., 2003). Recent OECD research on primary and secondary education -- where user choice is most debated -- suggests that parental choice has a positive effect on student attainment and does not lead to higher disparities in attainment (Sutherland and Price, 2007). ${ }^{10}$ An overview of user choice regulations for sub-central public services is given in Table 3.

9. In many countries the "reasonable distance" is a topic of much debate, and "closeness" of a service is a main quality feature. The number of potential alternative providers hence depends on population density but also on households' willingness and ability to spend on transport.

10. Actually both user choice and decentralisation -- i.e. giving more autonomy to sub-central governments and schools -- appear to have a positive impact on efficiency (Sutherland and Price, 2007). In a decentralized environment sub-central governments have considerable influence on school quality, which 


\section{[Table 3. User choice for sub-central services]}

25. User choice varies greatly across countries but less so across services (Table 4). Australia and Denmark grant free user choice to the services analysed in this document, while choice is quite restricted in Finland and in Switzerland. User choice is quite common in childcare and the hospital sector although for the latter may depend on whether or not a treatment can be obtained in an assigned hospital. ${ }^{11}$ User choice is most restricted in primary and secondary education, reflecting the traditional system where parents are assigned a school where they reside. In some countries users have free choice within their own jurisdiction -- municipalities, counties, school districts -- giving them limited choice, but are not allowed to select a provider in a neighbouring jurisdiction. In all countries users are free to choose between public and private providers (not shown in the table), although actual choice may be limited as in some countries private providers receive no government funding and hence have to levy fees.

26. User choice across jurisdictions brings with it some externality problems. If users have a choice, jurisdictions may be tempted to reduce their own service responsibilities and shift them onto others. Such inter-jurisdictional manoeuvrings may either result in a long-term under-provision of sub-central services, or lead to an excessive fiscal burden for jurisdictions that continue to cater for non-residents. User choice arrangements may even break down as jurisdictions have little incentive to accept users from neighbouring jurisdiction without proper compensation schemes. ${ }^{12}$ To ensure that user choice is beneficial for consumers and viable for all jurisdictions, SCGs may have to set up intergovernmental financial arrangements that take cross-border service use into account. Switzerland has designed a horizontal arrangement in vocational tertiary education that combines free school choice with a compensation for non-resident students, giving incentives for vocational schools to attract outside students (OECD, 2003). Denmark provides a voucher-like system for childcare allowing parents to use an institution outside their municipality of residence (questionnaire response).

\subsection{Market access and competition among providers}

27. Market access is an obvious complement to user choice. The welfare-promoting properties of user choice are much enhanced if they are matched by providers' rights to enter the market and compete for customers. In the countries and for the services under scrutiny here, private providers have the potential right to enter the market (see the section on private provision). However, free entry is sometimes limited by tendering, particularly in the technical services such as transport or waste collection. In the "social" services, actual competition between public and private providers may be distorted if SCGs provide little or no public funding for private providers, forcing them to levy user fees. More balanced funding arrangements can give users more choice, but those arrangements have to ensure that service demand may not reach financially unsustainable levels.

28. SCGs have a tendency towards service regulation that prevents private agents from entering the market (Joumard et al., 2003). Regulation can be particularly restrictive in some social services. The rules to open a hospital are sometimes so strong that private providers are almost entirely

in turn is one of the main criteria for parents to choose their place of residence. Choice of residence is an indirect form of user choice. "Direct" and "indirect" user choice may hence be substitutes to some extent, leading to similar efficiency results through two different channels.

11. In Denmark and the United Kingdom patients are allowed to choose a hospital only if the assigned hospital is not able to provide the required treatment within a certain delay (information from questionnaire responses).

12. Norwegian municipalities, responsible for a large number of social services, tended to shift responsibilities for schools and elderly care to neighbouring jurisdictions (OECD, 2002). US and Swiss central cities often provide services to the wider suburban area without being compensated (OECD, 2002). 
excluded from the general hospital sector. ${ }^{13}$ In some countries, opening a nursery requires high professional qualifications and administrative requirements to discourage flexible parental and neighbourhood self-organisation (e.g. Filippini and Iten, 2005). Moreover, a regulatory framework that differs across jurisdictions fragments the market and thereby reduces economies of scale and scope and discourages competition across SCG borders. While some services do indeed require careful government regulation, neighbourhood services where output is easy to monitor should be regulated in as simply a fashion as possible.

\subsection{Results for the intermediate indicator "user choice and competition among providers"}

29. The extent to which SCGs grant individual user choice and market access for private providers is measured by institutional indicator 2 "user choice and competition among providers". This intermediate indicator is based on five low-level indicators (LLIs): LLI-6 measures whether users have choice within their jurisdiction of residence, LLI-7 measures whether users have choice across jurisdictional borders, LLI-8 measures the extent to which private service providers have access to the market, LLI-9 whether SCGs grant both user choice and market access for service providers, and LLI-10 assesses central government's role in granting user choice and market access at the sub-central level. All information contained in the LLIs is described in the policy parts of this section. Coding for LLIs to obtain the intermediate indicator is shown in Table A1 in the Annex.

30. Numerical results for the intermediate indicator 2 display high values for Denmark, Australia and Belgium (Walloon part), and low values for Turkey, Norway, and Austria (Figure 9). User choice arrangements are particularly consistent in Denmark while there is some dispersion in Norway or Sweden. Averages for ILI-2 are higher than for ILI-1, suggesting that user choice is more developed than private provision and tendering. With a few exceptions, the within-country confidence intervals are relatively small, pointing at consistent user choice and competition arrangements.

\section{[Figure 6. Intermediate level indicator 2: user choice and competition]}

\section{5. $\quad$ Price signals in funding}

31. This section deals with the third branch of the market mechanism indicator tree shown in Figure 1 "price signals in funding”. The policy issues related to user fees and use-related funding mechanisms are first discussed and the section then presents the institutional indicator results measuring the extent to which SCGs use price signals when funding their services.

\subsection{User fees}

32. User fees cover all individual payments to public service providers, including collective, private co-payments through insurance schemes, in return for services provided. User fees can be beneficial both for containing excessive demand for and for fostering supply of public services. Since many sub-central services are well suited for individual pricing, user fees have become an important SCG revenue source. According to the questionnaire, user fees cover a significant part of cost in subcentral services like public transport and waste collection but less so in services like tertiary education, nursing homes and childcare. No user fees are generally levied in primary and secondary education. An overview on the level and intergovernmental composition of user fees in OECD countries is given in Figures 7 and 8, although these numbers must be handled with care (see Box 3).

\section{[Figure 7. User charges in OECD countries]}

13. This could be the case in the Netherlands where hospital care is almost entirely provided by non-governmental foundations. Although the market for hospitals is potentially open, new providers hardly come up, and private for-profit care is restricted to a few specialised clinics (information provided by questionnaire). 


\section{[Figure 8. User charges across levels of government]}

33. User fees make up a considerable part of public sector revenue in some countries, accounting for $2.3 \%$ of GDP or $6.3 \%$ of total government expenditure. Finland, New Zealand and Sweden have the highest fee-to-GDP ratio, while Switzerland, New Zealand and Finland have the highest fee-to-expenditure ratio. User fees are a typical SCG revenue source: in federal countries around $75 \%$ of fees accrue to local and state governments combined, while in a majority of unitary countries local government accounts for more than $50 \%$ of total user fee receipts. In a few countries fee revenue even exceeds revenue from local taxes (Greece, Ireland, and the Netherlands). Tax and fee revenue are positively correlated, i.e. SCGs with a higher tax share tend to have higher user fees. ${ }^{14}$ User fee structure across government function is not available but questionnaire responses suggest that most user fees at the sub-central level are levied for technical services such as public transport, water, and waste collection. In a few countries jurisdictions are allowed to differentiate user fees between residents and non-residents (see Box 4).

\section{Box 3. User fee data: handle with care}

Data on user fees are provided by the International Monetary Fund's Government Finance Statistics (GFS) only; the OECD does not currently provide statistics on user fees. User fees are denoted "sales of goods and services" and include all individual payments made to a government-owned agency. Although the statistics can give a useful impression of the scope of user fees across countries, data must be compared with care for several reasons:

Public versus private provision: User fees levied by a public provider enter the statistics while an identical type of revenue levied by a private provider does not. For instance, the revenues of the publicly-owned French or Czech Railways are counted as user fees while the revenues of the privately-owned British railway companies are not, entailing an unequal treatment of providers that differ in ownership only. Actually user fee statistics tell more about the size of a country's public sector than about the latter's propensity to apply the price mechanism.

Gross versus net accounting: Government accounts usually differentiate between in-house provision and provision by autonomous agencies. If a service is produced in-house, all expenditure and revenue including fees is accounted for (gross accounting) while if a service is produced by an agency a government's net contribution -- the subsidy -- is accounted for only (net accounting). User fees may therefore enter or not into the GFS depending on how a service is governed administratively.

User fees versus taxes: The borderline between user fees and taxes is not always easy to draw as some revenue sources are a blend of both revenue categories. The GFS manual itself asserts that if "fees are so high that they are clearly out of proportion to the cost of the services provided [ ...] such fees are classified as taxes". Depending on how "out of proportion" is seen across countries, similar revenue arrangements may be classified differently.

OECD countries may find it useful to set up a database on user fees, co-ordinated with Revenue Statistics and National Accounts

Source: IMF Government Finance Statistics

34. User fees can attenuate rising demand for sub-central services and environmentally sensitive goods, particularly if demand is price sensitive. In such cases, user fees are a lever for SCG to reduce budget pressure (OECD, 2003) ${ }^{15}$. User fees are less suited for demand management when services are not particularly price sensitive (e.g. in acute hospital care) and/or if service coverage is at $100 \%$ (e.g. primary and secondary education). User fees can also be a neat instrument for local and regional environmental policy. Proper pricing of environmentally sensitive services such as waste collection, water treatment, or transportation can help contain environmental degradation. Several countries charge waste collection fees based on the amount of waste produced or introduce congestion pricing

14. This is actually not surprising since both variables are a function of sub-central autonomy, i.e. the right to raise taxes and the right to levy user fees usually go hand in hand. More refined data analysis would be needed to test whether taxes and fees are substitutes or complements when expenditure needs are rising.

15. User fees for childcare may however reduce female participation in the labour market. 
schemes to cope with the externalities of private transport. ${ }^{16}$ If properly designed and reflecting both service demand and environmental impact, user fees may become the pivot of SCG ecological tax reform.

35. User fees can also raise revenue to relieve infrastructure bottlenecks or improve service quality. Financial constraints have prevented urban transport systems from coping with growing demand, which has led to considerable congestion and productivity losses (OECD, 2002). In most countries, user fees cover $50 \%$ or less of urban public transport cost, depriving transport investment funds from sufficient revenue. As the price elasticity of urban transport is very low (Victoria Transport Policy Institute, 2007), higher ticket prices is a way of generating resources for new transport infrastructure. In tertiary education, higher tuition fees can help fund additional investment in teaching capacities and quality and ease supply constraints (Oliveira-Martins, 2007). Although higher tuition fees could potentially reduce demand, some country experience suggests that combining user fees and measures targeted at poorer students actually increases enrolment. ${ }^{17}$ As fees should be used for the services for which they are levied, their revenue should remain with providers -- transport companies, universities etc. -- or be earmarked for investments in those services if they enter general government accounts.

\section{Box 4. Differentiating user fees between residents and non-residents}

According to questionnaire responses, only in a few countries are jurisdictions allowed to differentiate the level of user fees between residents and non-residents. They do so particularly in cases where services are financed through sub-central taxes, and they justify price differentiation on the grounds that non-residents do not pay taxes to cover service cost. While price differentiation at first sight erects barriers against the free flow of people, it can be seen as a means for demand management and for generating additional resources, and it enhances a jurisdiction's scope for negotiating horizontal financial arrangements. Price differentiation between residents and non-residents can hence reduce free-riding and allow recovering a part of service cost, either through individual or through collective payment arrangements. The potential to differentiate prices reduces incentives for an individual SCG to shift service responsibility onto other jurisdictions and opens the way for a more balanced division of spending across jurisdictions.

Source: questionnaire responses

36. Fiscal considerations, service characteristics and the wider administrative environment impose constraints against stronger reliance on user fees. In many countries, SCGs have an incentive to levy user fees instead of taxes for fiscal reasons, so regulation may require that fees be introduced on a strict cost-recovery basis only. ${ }^{18}$ Many sub-central services are monopolistic in nature, and the decision on level and structure of user fees should be allocated to government rather than providers. For some services such as health care, where consumers are unsure about actual needs and where user fees could induce a spiral of supply-induced demand, SCG may have to set limits on the right of providers to define user fee levels. More generally, some country evidence suggests that user fees are best applied in a framework where providers are competing with each other, where SCG budgets report service revenues and costs in a transparent way and where citizens have some control over fees (Groot and Budding, 2004).

16. London in 2003 introduced an ambitious congestion pricing scheme aiming not primarily at raising revenue but at containing congestion and negative environmental impact (Leape, 2006).

17. The introduction of fees and income-contingent student loans in Australia and New Zealand was met with an increase of enrolments by 50\% and 90\% respectively (OECD, 2007b, US Survey).

18. Many fiscal equalisation arrangements do not include user fees into the sub-central revenue base, so SCG have some incentives to replace taxes by fees (Groot and Budding, 2004). 


\subsection{Vouchers and other use-related funding}

37. Vouchers and other "money follows the user" arrangements link public subsidies to service demand. Such arrangements are intended both to increase providers' responsiveness to consumer tastes and preferences and to contain service cost. While "pure" voucher systems where consumers receive a lump sum from government are still unknown, use-related funding where government pays providers according to a use indicator is becoming more common. Examples include schools funded according to the number of pupils or nursing homes funded by the number of residents. Voucher-like subsidies are often risk- or cost-adjusted, e.g. by weighing per-student payments with a need factor or the cost of a curriculum. The funding of hospitals based on diagnosis-related groups is currently the most sophisticated funding system. Use-related funding varies across countries, but "full capitation" whereby the number of users entirely defines the amount reimbursed to a provider is still the exception (Table 4). User-related funding is applied less often in public transport and waste collection, partly because user fee revenue already reflects consumer demand.

\section{[Table 4. Use-related funding mechanisms]}

38. As with other market mechanisms, vouchers have advantages but also pose risks for sub-central governments. Use-related funding is usually a corollary of user choice but that need not be the case. ${ }^{19}$ User choice without the corresponding funding can lead to service degradation (see section on user choice), and user-related funding without user choice leaves providers with few incentives to raise standards (Burger et al., 2006). Finally, voucher systems may become victims of their own success: given that service demand may rise once providers improve service levels, sub-central budget may come under pressure. Use-related funding is hence best applied for services with low price elasticity -- e.g. compulsory education or hospital care -- or where access can be at least partially regulated, e.g. in tertiary education. The advantages and limits of use-related funding mechanisms have been discussed in several OECD publications and for services like education, nursing homes and childcare (Lunsgaard 2002, Joumard et al., 2003, Sutherland and Price, 2007, Erlandsen 2007).

\subsection{Results for the intermediate indicator 3 "price signals in funding"}

39. The extent to which SCGs apply user fees and use-related funding in service provision is measured by institutional indicator 3 "price signals in funding". This intermediate indicator is based on five low-level indicators (LLIs): LLI-11 measures the percentage of cost covered by user fees, LLI-12 assesses who decides on the level of fees and where the revenues go, LLI-13 is a consistency indicator assessing decision-making processes, LLI-14 measures the extent to which SCGs apply userelated funding ("vouchers"), and LLI-15 measures the share of use-related to total government funding. All information contained in the LLIs is described in the policy parts of this section. Coding for LLIs to obtain the intermediate indicator is shown in Table A1 in the Annex.

40. The numerical results for intermediate indicator 3 (Figure 9), show high values for Switzerland, Ireland and the Netherlands and low ones for Italy, Mexico and Portugal. Funding arrangements are particularly consistent in Switzerland and Australia. Averages for ILI 3 are below the averages for ILI 1 and ILI 2, pointing at weak use-related funding. Also, variation across countries is relatively small, suggesting that there is no real vanguard for use- and performance-related funding.

\section{[Figure 9. Intermediate level indicator 3: price signals in funding]}

\footnotetext{
19. In some countries hospital funding relies on user-related funding but users have no actual choice among hospitals
} 


\section{Summary indicator of the use of market mechanisms and the policy reform gap}

\subsection{Summary indicator: market mechanisms in public service provision}

41. This section presents the summary or composite indicator that reflects, in a single number, the extent to which sub-central governments rely on market mechanism when providing public services. The composite indicator summarises the three intermediate level indicators (ILIs) elaborated in Sections 3 to 5. To construct the composite indicator on the basis of the three ILIs, two different aggregation methods are applied, additive aggregation -- applying the random-weights technique -and the multiplicative aggregation. This latter method favours arrangements with high institutional consistency across intermediate indicators (OECD, 2005, see also the Annex). Given the considerable correlation between ILIs, a third technique called "principal component factor analysis" was also applied, whose results did however hardly differ from multiplicative aggregation.

\section{[Figure 11. Summary indicator: use of market mechanisms in public service provision]}

42. The composite indicator shows the use of market mechanism in public service provision across selected OECD countries (Figures 11a and 11b). Values using the additive method are high for Australia, Denmark and the Netherlands, while they are low for Mexico, Turkey, and Italy. Ranking order for the additive and the multiplicative composite indicator do not differ much, suggesting relatively consistent market mechanism arrangements across countries. Small confidence intervals for most countries also suggest relatively high consistency. Variation across countries is rather small, which points at the "compensation" mentioned earlier: countries often compensate low values for one service or for one intermediate indicator with higher values for another, which leads to little variation of the composite indicator across countries.

\subsection{Measuring the policy reform gap}

43. This section presents an indicator that measures the gap between actual market arrangements and a number of normative benchmarks, i.e. the difference between "what is" and "what should be". Actual market mechanism arrangements are derived from the analysis in the previous sections. Benchmarks are derived using a number of OECD recommendations on market mechanisms published recently. The "policy reform gap" indicator is hence constructed by confronting actual market mechanism use with OECD reform proposals. The policy reform gap indicator is servicespecific since recommendations vary across services: e.g. while "user choice" is a common recommendation in primary and secondary education, "open tendering" is a common recommendation in public transport or waste collection (Table 5).

\section{[Table 5. Market mechanism recommendations]}

44. Considering that the number of recommendations varies across services, the policy gap indicator is constructed in two ways: first, as an average of the difference between the actual arrangement and the benchmark; second, as the sum of the differences between the actual market arrangement and the benchmark. The sum indicator takes the number of reform proposals for each service into account while the average indicator is insensitive to the number of benchmarks. The sum indicator hence acknowledges that the reform gap is actually higher the higher the number of reform proposals for a service. Technical details are described in the Annex.

\section{[Figure 12. Policy reform gap for sub-central public services]}

45. Figures 12a and 12b show the policy reform gap for each service across all countries. For each figure, a longer bar means a higher reform gap or a higher reform potential. In general, "social services" like education or health have a higher reform potential than "technical services" like public transport or waste collection. What follows is a short account of the results: 
- Primary education: In both figures, primary education covers an intermediate rank across sub-central services. The extent of the policy gap is mainly influenced by low indicator values for use-related funding and the right of private schools to obtain some government funding, while user choice is rather advanced in the countries under scrutiny.

- Secondary education: Secondary education shows almost the same values as primary education. This is not surprising as in most countries the institutional arrangements for both education levels are almost identical. Again the reform potential lies in the funding mechanism, while user choice is quite advanced.

- Tertiary education: Tertiary education has the highest reform potential in the average figure and an intermediate position in the sum indicator. Indicator results show that little reliance on user fees for tertiary education is the single most reason for the high policy reform gap.

- Hospitals: Hospitals cover an intermediate-low position in both figures. Reform potential lies in more user choice and in advanced use-related funding such as diagnosis-related groups. Access to the market for private hospitals is relatively open, although the indicator may underestimate difficulties for private providers to be funded on the same ground as public hospitals.

- Public Transport: Public transport is ranked low in both figures, reflecting a rather strong reliance on market mechanisms. Competitive tendering has become more frequent in local and regional transport, particularly for buses, although all jurisdictions have not yet fully implemented standardised tendering rules. User fees cover a significant part of operating cost.

- Nursing homes: Nursing homes rank relatively high in both figures. The reason is that user choice is often not guaranteed, and if it is, it is usually restricted to the resident's jurisdiction. Also user fees often cover a small part of total cost only.

- Childcare: Childcare covers a similar position as nursing homes. User choice is a little less restricted, while fees tend to cover a somewhat larger part of total cost.

- Waste collection: Tendering has become common for waste collection in most countries. In some countries there is even free market access for industrial waste collection. Waste disposal, on the other hand, is mostly a public monopoly.

\section{Trade-offs and side effects of market mechanisms in public service provision}

46. Market mechanisms can improve efficiency of public services by introducing competitive forces, by increasing user choice and by relying on more price signals in funding arrangements. However, some trade-offs and side-effects may become apparent when market mechanisms are used more widely. Extending market mechanisms to SCG public services can run counter to the objective of universal public service access, with undesirable distributional effects, both social and geographic in nature. And central government measures to implement market mechanisms at the sub-central level may conflict with local choice, i.e. SCGs' desire to adapt their arrangements to local circumstances and needs. This last section gives an overview on trade-offs between efficiency and equity and between efficiency and local accountability. 


\subsection{Equity concerns}

47. The following paragraphs give an overview of the undesirable effects of market mechanisms may have on equity and the policies sub-central and central government have developed to cope with them.

- User fees: User fees may exclude poorer segments of the population from public services. User fees for hospital or outpatient care may conflict with the principle of universal access. Higher fees for public transport could exclude people from access to transport, particularly those without car. Higher user fees in tertiary education may exclude students from poor families although the efficiency-equity conflict is lower as the current funding rules favour well-off households.

- User choice: User choice itself need not have any distributional consequences but could have adverse effects when combined with more freedom for providers. Providers may be able to screen potential users, thereby filtering social groups with higher-than-average cost. Most funding systems lack the sophistication to deal with such filtering, and some groups may be denied effective access to services such as schools or hospitals.

- $\quad$ Tendering and other forms of contracting out: Tendering itself has little distributional effect. However, depending on the standards imposed on providers with respect to service coverage -- e.g. in public transport -- they may withdraw services for certain social groups or from certain areas. Also, if not regulated properly, service standards may decline after privatisation or tendering of services.

48. Governments, both central and sub-central, have policy options to cushion potential adverse effects of increased market mechanisms:

- Setting minimum standards: Central and sub-central governments often set social and/or geographical minimum standards for service providers, including in tenders. Standards may take the form of detailed prescriptions such as a settlement's right to a school if the number of pupils exceeds a certain threshold, or its right to a certain number of daily bus connections. In some countries, central government requires SCG to provide minimal standards and also co-funds them.

- Providers must accept any user: Countries with user choice generally require providers to accept any potential user. This holds particularly for schools, hospitals and public transport where legal provisions forbid providers to turn users away. Universal access rights are meant to ensure that providers cannot exclude certain social groups, although screening and selection sometimes works through informal channels and is difficult to detect.

- Lower fees for users in need. Most countries set lower user charges and fees for certain social groups. Low-income elderly pay lower fees in nursing homes, the fees for childcare institutions are linked to parent's income, and public transport companies offer lower fees for students and unemployed. In some cases lower revenues must be borne by the provider, but in most cases the cost of fee reductions based on distributional motives is covered by (central or sub-central) government.

- Direct income support: Means-tested income support is a social policy measure meant to increase the individual or household budget. Government loan guarantees with incomecontingent repayment in tertiary education could also be mentioned here. Direct income support enables users to pay for priced public services. Compared to subsidizing a service, 
direct income support increases choice as it allows users to select level and structure of services they want to consume and pay for.

- Central government pays grants to SCG: To warrant what is called "universal service", central government often pays earmarked grants for specific services or a more general block grant. Another way to provide additional funding is fiscal equalization which leaves SCGs the possibility of providing universal access without compelling them (Blöchliger and Charbit, 2007).

- Vouchers and use-related funding. Some market mechanisms are inherently linked to an equity objective. The most advanced system is the introduction of voucher and other userelated systems that give each individual the same access right to a service. In order to take account of differences in the cost of catering to certain social groups, providers may receive cost-or need-adjusted payments, usually coupled to the condition that providers -- such as for schools, hospitals, elderly and childcare institutions -- may not turn users away.

\subsection{Sub-central accountability}

49. As has been pointed out in this paper, the application of effective market mechanisms may sometimes require central government intervention, such as establishing uniform contracting rules or ensuring user choice across jurisdictional borders. Central governments may want to ensure that SCGs make use of economies of scale and scope or refrain from local protectionism when establishing market like-arrangements. Moreover, in many countries the central government defines sub-central service delivery in terms of national standards and requirements. Such central rules may conflict with the need for SCGs to adapt some regulations to local circumstances and may also prevent SCGs from being accountable for their own services. Finally, SCGs may see their role not only in determining the outcome but also in governing service production, and may fear that more market means less control over a service.

50. Countries have developed various measures to maintain sub-central autonomy while ensuring that the "internal public service market" is kept open and equal service access continued. Some countries enact market mechanism framework legislation- e.g. on contracting - while leaving its implementation to sub-central governments. Some refrain from setting minimum standards for subcentral services but instead apply fiscal equalisation systems that allow SCGs to reach those standards without actually compelling them. Finally, instead of legislating, central governments may provide comparable information and benchmarking on the use of market mechanisms and the performance of the sub-central public sector -- this is the topic of the parallel paper "Indicator systems" [COM/CTP/ECO/GOV(2007)4] 


\section{REFERENCES}

Allen, G. (2001), “The Private Finance Initiative”, House of Commons Research Paper 01/117, London.

Bekken, J.T., F. Longva, N. Fearnley, E. Frøysadal and O. Osland (2006), "Procurement and Contracts for Local Bus Services”, TØI Report 819/2006. Available on www.toi.no.

Blöchliger, H. and C. Charbit (2007), "Fiscal Equalisation in OECD Countries”, Working Paper No. 4 of the OECD Fiscal Federalism Network, Paris, www.oecd.org/ctp/federalism.

Blöchliger, H. and D. King (2006), "Less Than You Thought: The Fiscal Autonomy of Sub-Central Governments”, OECD Economic Studies No. 43, pp. 155-186, OECD, Paris.

Burger, S., C. Propper and D. Wilson (2006), "Will More Choice Improve Outcomes in Education and Health Care? Evidence from Economic Research”, CMPO, University of Bristol.

Cambini, C and M. Filippini (2003), “Competitive Tendering and Optimal Size in the Regional Bus Transportation Industry: Examples from Italy”, Annals of Public and Cooperative Economics 74:1 2003, pp. 163-182.

Deutsches Institut für Urbanistik (2005), Public Private Partnership Projekte. Eine aktuelle Bestandesaufnahme in Bund, Ländern und Kommunen, Berlin.

Dijkgraaf, E., R.H.J.M. Gradus and B. Melenberg (2003), “Contracting Out Refuse Collection”, Empirical Economics, 28, pp. 553-570.

Erlandsen, Espen (2007): 555. Improving the efficiency of health care spending: selected evidence on hospital performance, Economics Department Working Paper 555, OECD, Paris

Farsi, M. and M. Filippini (2004), “An Empirical Analysis of Cost Efficiency in Non-Profit and Public Nursing Homes”, Annals of Public and Cooperative Economics 75:3 2004, pp. 339-365.

Filippini, R. and R. Iten (2005), Demand Oriented Supply Management of Extrafamilial Child Care, Research Programme on Childhood, Youth and Intergenerational Relations, Bern, www.nfp52.ch/e_dieprojekte.cfm.

Frey, R. (2004), “Öffentliche Unternehmen zwischen Markt und Politik”, in F. Jaeger, Staatsmonopole als Wachstumskiller, Zürich.

Globerman, S. and A. Vining (1996), A Framework for Evaluating the Government Contracting-Out Decision, Public Administration Review 56, pp. 577-586.

Gonand, F., I. Joumard and R. Price (2007): Public spending efficiency: institutional indicators in primary and secondary educations. Economics Department Working Paper 543, OECD, Paris. 


\section{COM/CTPA/ECO/GOV/WP(2008)6}

Groot, T. and T. Budding (2004), The Influence of New Public Management Practices on Product Costing and Service Pricing Decisions in Dutch Municipalities, Financial Accountability \& Management, Vol. 20(4).

Institut de la Gestion Délégué (2006), Les partenariats public-privés en France, Paris (http://igd.mathena-agence.com/html/publ/docp/).

Instituto das Estradas de Portugal (2005), The Portuguese Motorway Concessions Programme 19982007, Lisbon (found under http://www.cnc-piarc-aipcr.ca/documents/PortugalPPP.ppt).

Jensen, P. and R. Stonecash (2004), "The Efficiency of Public Sector Outsourcing Contracts: A Literature Review”, Melbourne Institute Working Paper No. 29/04, The University of Melbourne, http://www.melbourneinstitute.com.

Joumard, I., P. Kongsrud, Y. Young-Sook Nam and R. Price (2003), “Enhancing the Cost Effectiveness of Public Spending: Experience in OECD Countries”, OECD Economic Studies 37, OECD, Paris.

Kahn, A. (1988), The Economics of Regulation. Principles and Institutions, Cambridge, MIT Press.

Karlaftis, M. and P. MacCarthy (2002), "Cost Structures in Public Transit: a Panel Data Analysis”, Transportation Research 38, pp. 1-18.

Leape, J. (2006), “The London Congestion Charge”, Journal of Economic Perspectives 20, pp. 157-176.

Looney, J. (1998), Outsourcing State and Local Government Services, Quorum Books, London.

Lunsgaard, J. (2002), Competition and Efficiency in Publicly Funded Services, OECD Economic Studies 35/2, pp. 80-128, OECD, Paris.

Ministry of Transport: Evaluation of the Finnish Public Transport System (2003), http://www.mintc.fi/www/sivut/dokumentit/julkaisu/julkaisusarja/2003/Evaluation\%20of\%20th e\%20Finnish\%20Public\%20Transport\%20System.pdf)

Mizell, L. (2008): Promoting Performance: Using Indicators to Enhance the Effectiveness of Sub central Spending, Working Paper No. 6, Fiscal Network, OECD, Paris

Nardo, M., et al. (2005), "Handbook on Constructing Composite Indicators: Methodology and User Guide”, OECD Statistics Working Paper, [STD/DOC(2005)3], OECD, Paris.

OECD (2000), Competition in Local Services: Solid Waste Management, [DAFFE/CLP(2000)13], OECD, Paris.

OECD (2002a), Economic Surveys, Norway, Paris.

OECD (2002b), Economic Surveys, Switzerland, Paris.

OECD (2002c), Impact of Transport Infrastructure Investment on Regional Development, OECD, Paris.

OECD (2003), Reviews of National Policies for Education: Tertiary Education in Switzerland, OECD, Paris. 
OECD (2005), "Regulating Market Activities in the Public Sector”, OECD Journal of Competition Law and Policy, pp. 21-124, OECD, Paris.

OECD (2006a), Economic Surveys, Germany, Paris.

OECD (2006b), “Enhancing Beneficial Competition in the Hospital Sector”, OECD Journal of Competition Law and Policy, pp. 153-247, OECD, Paris.

OECD (2006c), "Structural Reform in the Rail Industry”, OECD Journal of Competition Law and Policy, pp. 67-176, OECD, Paris.

OECD (2007a), Competitive Tendering of Rail Services, OECD, Paris (forthcoming).

OECD (2007b), Economic Surveys, United States, Paris.

Oliveira-Martins, J. (2007c), “The Policy Determinants of Investment in Tertiary Education”, OECD Economics Department Working Papers No. 576, OECD, Paris.

Shaoul, J. (2005), “A Critical Financial Analysis of the Private Finance Initiative: Selecting a Financing Method or Allocating Economic Wealth?”, Critical Perspectives on Accounting, pp. 441-471.

Sutherland, D. and R. Price (2007), "Linkages Between Performance and Institutions in the Primary and Secondary Education Sector”, OECD Economics Department Working Papers No. 558, OECD, Paris.

Sutherland, D., R. Price and I. Joumard (2005), “Sub-central Government Fiscal Rules”, OECD Economic Studies 41, OECD, Paris.

Toner, J.P. (2002), The London Bus Tendering Regime - Principles and Practice, Institute for Transport Studies, University of Leeds.

UK Treasury (2006), PFI: Strengthening Long-term Partnerships, London.

Ventura, J., E. Gonzalez and A. Carcaba (2004), "Efficiency and Programme Contract Bargaining in Spanish Public Hospitals”, Annals of Public and Cooperative Economics 75:4 2004, pp. 549-573.

Victoria Transport Policy Institute (2007), Transport Elasticities: How Prices and Other Factors Affect Travel Behavior, http://www.vtpi.org/tdm/tdm11.htm.

Waldmann, E. (2003), Die Elektrizitätswirtschaftsordnung, Institut du fédéralisme, Université de Fribourg.

Warner, M. and G. Bel (2006), Competition or Monopoly? Comparing Privatization of Local Public Services in the United States and Spain. 
Table 1. Public services covered

\begin{tabular}{|c|c|c|c|c|c|c|c|c|}
\hline $\begin{array}{c}\text { COFOG 1 } \\
\text { (policy area) }\end{array}$ & \multicolumn{3}{|c|}{ Education } & $\begin{array}{c}\text { Health } \\
\text { care }\end{array}$ & Economic affairs & \multicolumn{2}{c|}{ Social protection } & $\begin{array}{c}\text { Environmental } \\
\text { protection }\end{array}$ \\
\hline $\begin{array}{c}\text { COFOG 2 } \\
\text { (service } \\
\text { category) }\end{array}$ & Primary & Secondary & Tertiary & Hospitals & Public transport & $\begin{array}{c}\text { Nursing } \\
\text { homes }\end{array}$ & $\begin{array}{c}\text { Childcare } \\
\text { institutions }\end{array}$ & $\begin{array}{c}\text { Waste collection } \\
\text { and disposal }\end{array}$ \\
\hline
\end{tabular}

Table 2. Share of public services provided by private providers

In percent of users served

\begin{tabular}{|c|c|c|c|c|c|c|c|c|c|}
\hline & $\begin{array}{l}\text { Primary } \\
\text { education }\end{array}$ & $\begin{array}{l}\text { Lower } \\
\text { secondary }\end{array}$ & $\begin{array}{c}\text { Tertiary } \\
\text { vocational } \\
\text { education }\end{array}$ & Hospitals & $\begin{array}{c}\text { Public } \\
\text { transport }\end{array}$ & $\begin{array}{l}\text { Nursing } \\
\text { homes }\end{array}$ & $\begin{array}{l}\text { Childcare } \\
\text { institutions }\end{array}$ & $\begin{array}{c}\text { Waste } \\
\text { collection }\end{array}$ & Average \\
\hline Australia & 28.7 & 35.4 & 2.9 & 64 & 98.0 & 91.0 & 66.2 & 95.0 & 60.1 \\
\hline Austria & 4.5 & 7.8 & 30.6 & & 0.0 & & 26.6 & & 13.9 \\
\hline Belgium & 54.7 & 56.6 & 52.4 & & & & 53.5 & & 54.3 \\
\hline \multicolumn{10}{|l|}{ Canada } \\
\hline Czech Republic & 1.1 & 1.8 & 32.1 & & & & 1.4 & & 9.1 \\
\hline Denmark & 11.7 & 23.4 & 0.9 & 2 & 85.0 & 79.0 & & 67.0 & 38.4 \\
\hline Finland & 1.2 & 4.1 & 29.6 & 4 & 80.0 & 12.0 & 8.1 & 100.0 & 29.9 \\
\hline France & 14.7 & 21.4 & 28.0 & 15 & & & 12.7 & & 18.4 \\
\hline Germany & 2.9 & 7.3 & 36.1 & & & & 58.8 & & 26.3 \\
\hline Greece & 7.5 & 5.4 & 0.0 & & & & 3.4 & & 4.1 \\
\hline Hungary & 5.9 & 6.7 & 39.6 & & & & 4.4 & & 14.1 \\
\hline Iceland & 1.1 & 0.8 & 39.5 & & & & 7.7 & & 12.3 \\
\hline Ireland & 1.0 & 0.0 & 7.2 & 13 & & 66.0 & 46.5 & 55.0 & 27.0 \\
\hline Italy & 6.9 & 3.5 & 14.8 & 14 & 5.0 & & 28.4 & & 12.1 \\
\hline Japan & 0.9 & 6.2 & 91.2 & & & & 65.7 & & 41.0 \\
\hline Korea & 1.3 & 19.8 & 85.0 & & & & 77.1 & & 45.8 \\
\hline Luxemburg & 6.9 & 19.9 & 0.0 & & & & 6.3 & & 8.3 \\
\hline Mexico & 8.1 & 12.6 & 3.7 & & & & 10.6 & & 8.8 \\
\hline Netherlands & 68.9 & 75.9 & 0.0 & 100 & & & 69.7 & 42.0 & 59.4 \\
\hline New Zeal and & 11.9 & 16.0 & 26.2 & & & & 43.8 & & 24.5 \\
\hline Norway & 1.9 & 2.3 & 35.8 & & 62.0 & 7.0 & 41.0 & 13.0 & 23.3 \\
\hline Poland & 1.4 & 2.1 & 20.8 & & & & 6.6 & & 7.7 \\
\hline Portugal & 10.2 & 11.5 & 50.0 & 5 & & 15.0 & 47.4 & & 23.2 \\
\hline Slovak Republic & 4.5 & 5.3 & 12.7 & & & & 0.7 & & 5.8 \\
\hline Spain & 32.0 & 32.4 & 22.5 & 16 & 11.5 & 22.3 & 35.1 & 0.0 & 21.5 \\
\hline Sweden & 5.6 & 6.3 & 34.9 & & 73.0 & 14.0 & 14.1 & & 24.7 \\
\hline Switzerland & 3.8 & 7.1 & 70.0 & 22 & & 33.0 & 6.8 & & 23.8 \\
\hline Turkey & 1.5 & 0.0 & 2.0 & & & & 3.9 & & 1.9 \\
\hline United Kingdom & 5.0 & 6.4 & 100.0 & & & & 8.5 & & 30.0 \\
\hline United States & 10.3 & 8.8 & 14.6 & & & & 40.1 & & 18.5 \\
\hline Unweighted average & 10.9 & 14.0 & 30.5 & 25.5 & 51.8 & 37.7 & 28.4 & 53.1 & \\
\hline
\end{tabular}

Source: Education at a Glance, Health database, Joumard et al., (2003), national sources and questionnaire responses. Indicator mostly used: for education: number of students, for hospitals: patient-beds, for public transport: number of passengers or number of companies, for nursing homes: number of patients, for childcare: number of children in institutions, for waste: not indicated. For Spain, National Accounts data were used for hospitals, nursing homes, public transport, and waste. 


\section{COM/CTPA/ECO/GOV/WP(2008)6}

\section{Table 3. User choice for sub-central services}

By country and by service

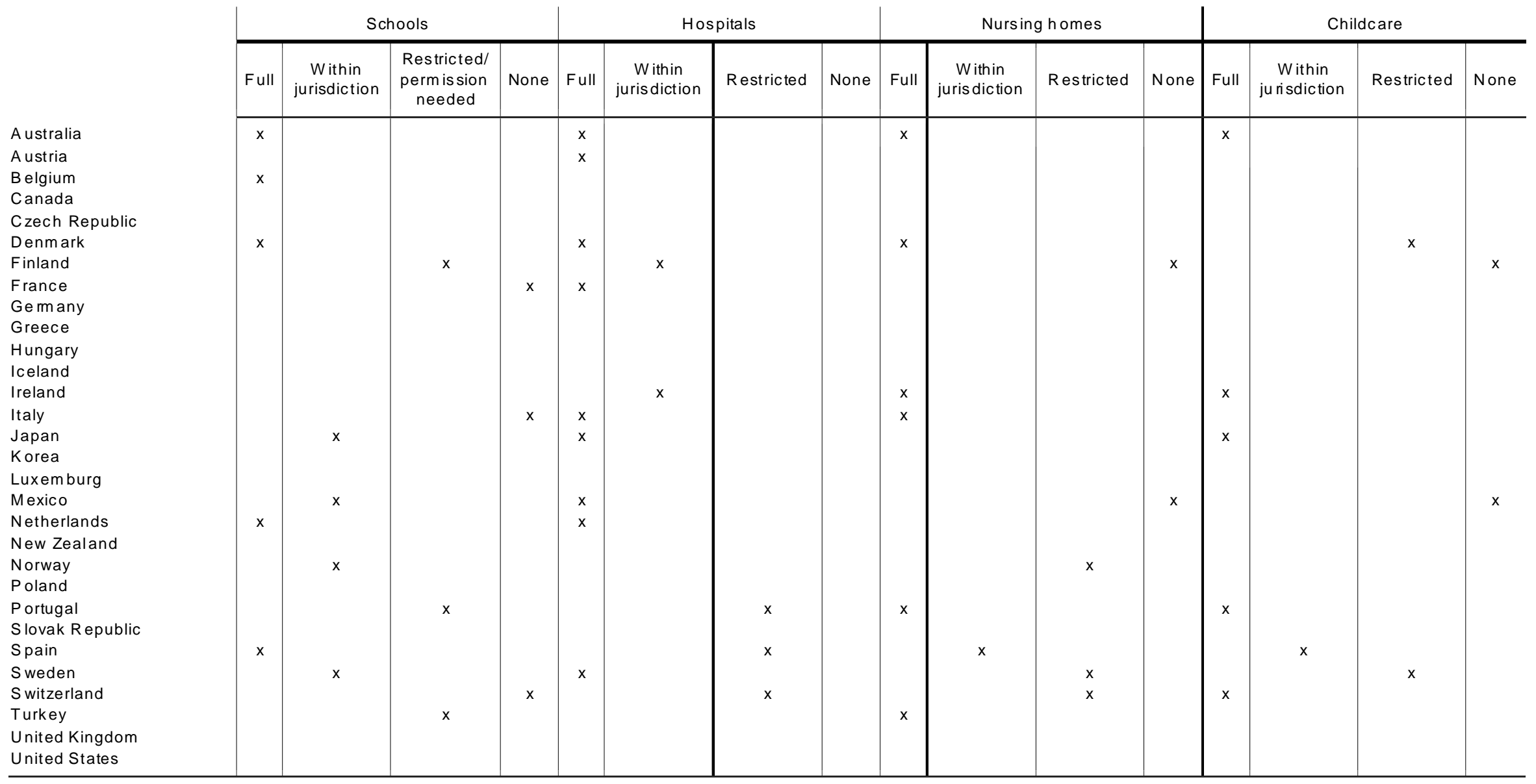

Source: Questionnaire responses, Gonand, Joumard and Price (2007) 
Table 4. Use-related funding mechanisms

By country and by service

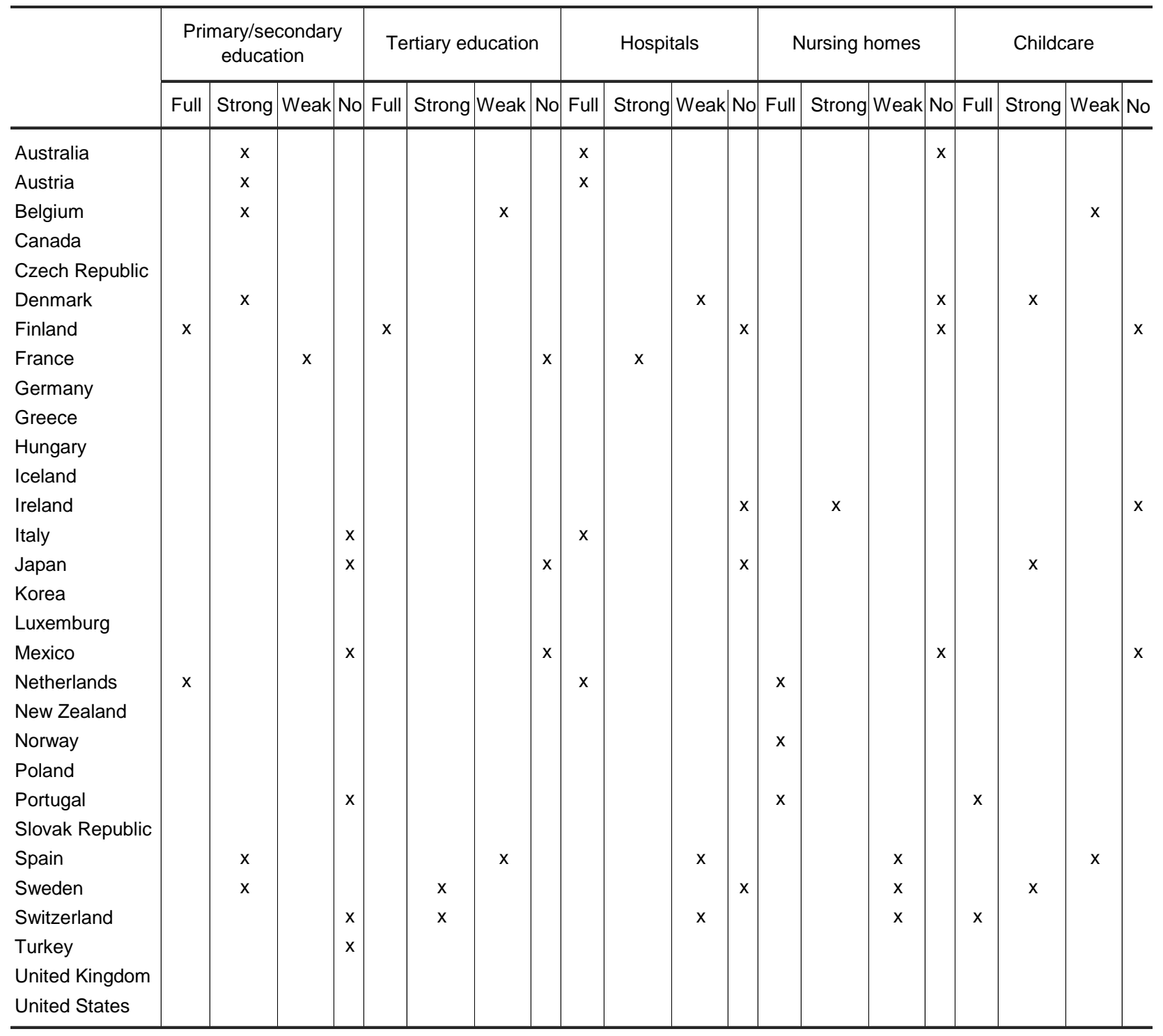

Note on column headings:

"Full": service is $100 \%$ funded according to use

"Strong": service is funded between 50 and $100 \%$ according to use

"Weak": service is less than $50 \%$ funded according to use.

Source: Questionnaire responses, Erlandsen (2007). 
COM/CTPA/ECO/GOV/WP(2008)6

Table 5. Market mechanism recommendations

OECD policy reform proposals across public services

\begin{tabular}{|l|l|}
\hline \multicolumn{1}{|c|}{ Public service } & \multicolumn{1}{c|}{ Market mechanisms recommended } \\
\hline Primary education & User choice, use-related funding, government funding of private providers \\
\hline Secondary education & User choice, use-related funding, government funding of private providers \\
\hline Tertiary education & User fees \\
\hline Hospitals & User choice, use-related funding, market access for providers \\
\hline Public Transport & User fees, open tendering \\
\hline Nursing homes & User choice, user fees \\
\hline Childcare & User choice, user fees \\
\hline Waste collection & Open tendering \\
\hline
\end{tabular}

Note: Benchmarking of performance was also recommended in many instances. Since little information was obtained on how benchmarking was effectively used, no policy reform gap could be calculated. For more information on performance benchmarking see Mizell (2008)

Source: Collected from: Lunsgaard (2004), Joumard et al., (2003), Joumard and Kongsrud (2003), Gonand et al., (2007), Docteur and Oxley (2003), OECD (2006, railways), OECD (2006, hospitals), OECD (2000, solid waste), OECD (2005, competition in public services) and various country surveys. 


\section{COM/CTPA/ECO/GOV/WP(2008)6}

Figure 1. Market mechanisms in public service provision: indicator tree

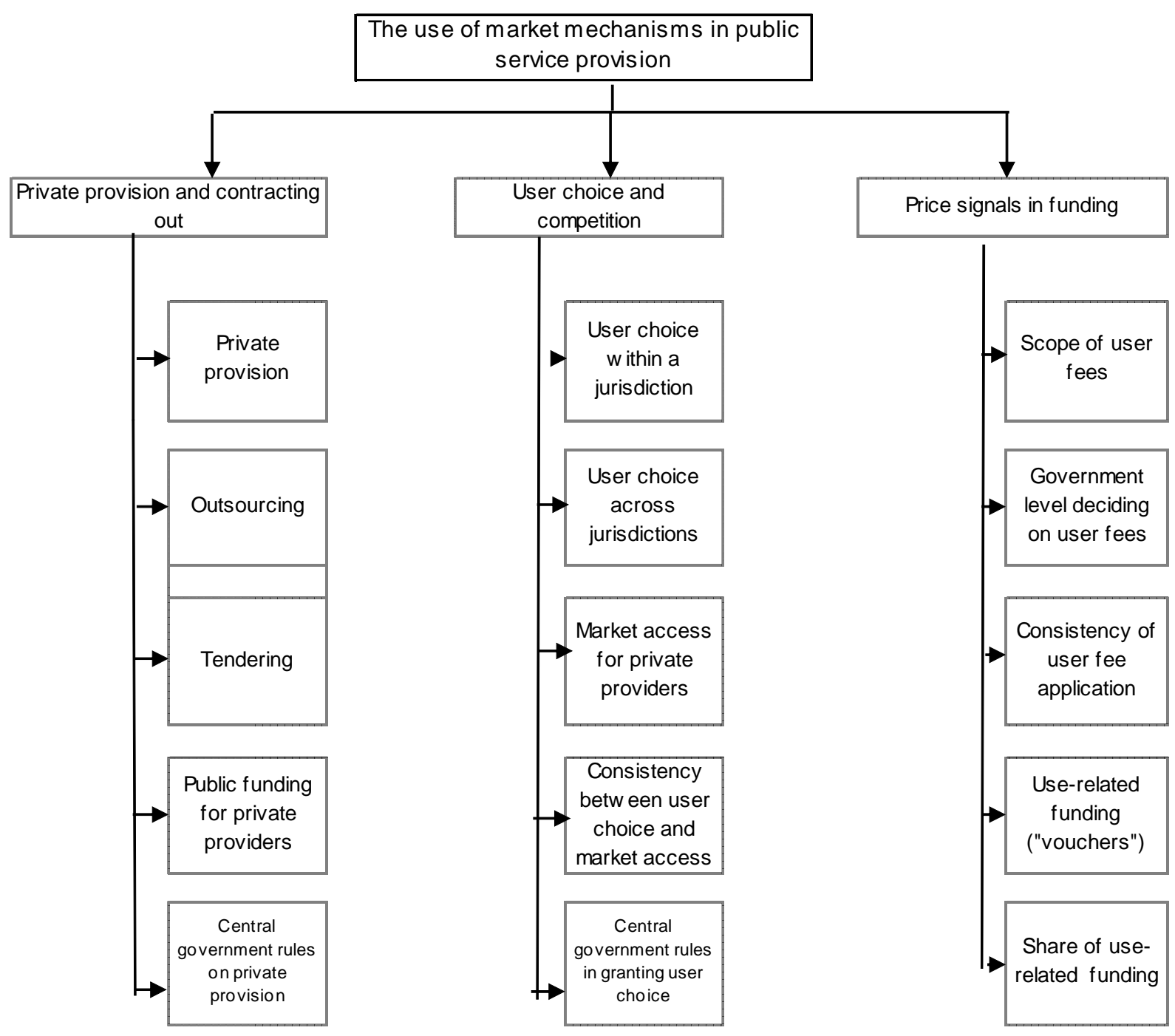


Figure 2. Decentralisation of public spending, 2005

Share of sub-central in total government expenditure, percent

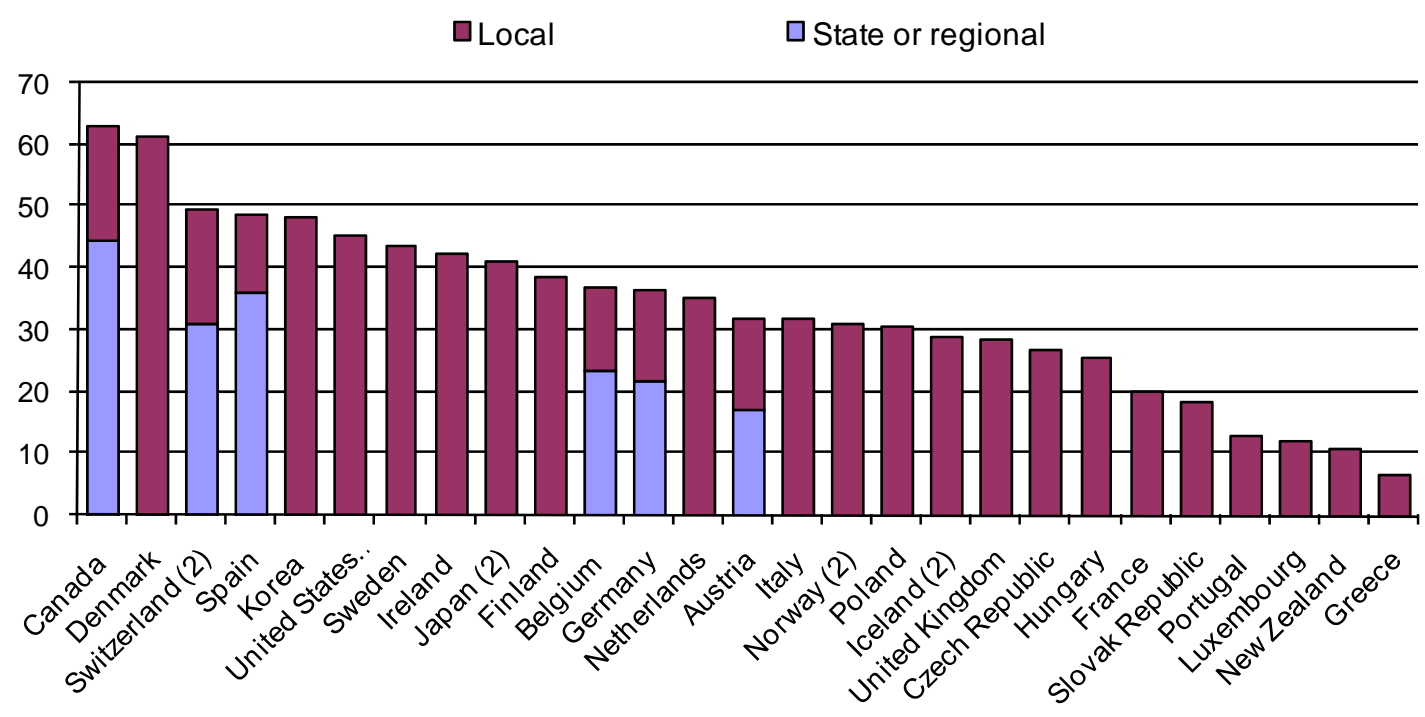

Figure 3. Decentralisation of public spending, evolution 1995-2005

Change in the share of sub-central in total government expenditure, percentage points

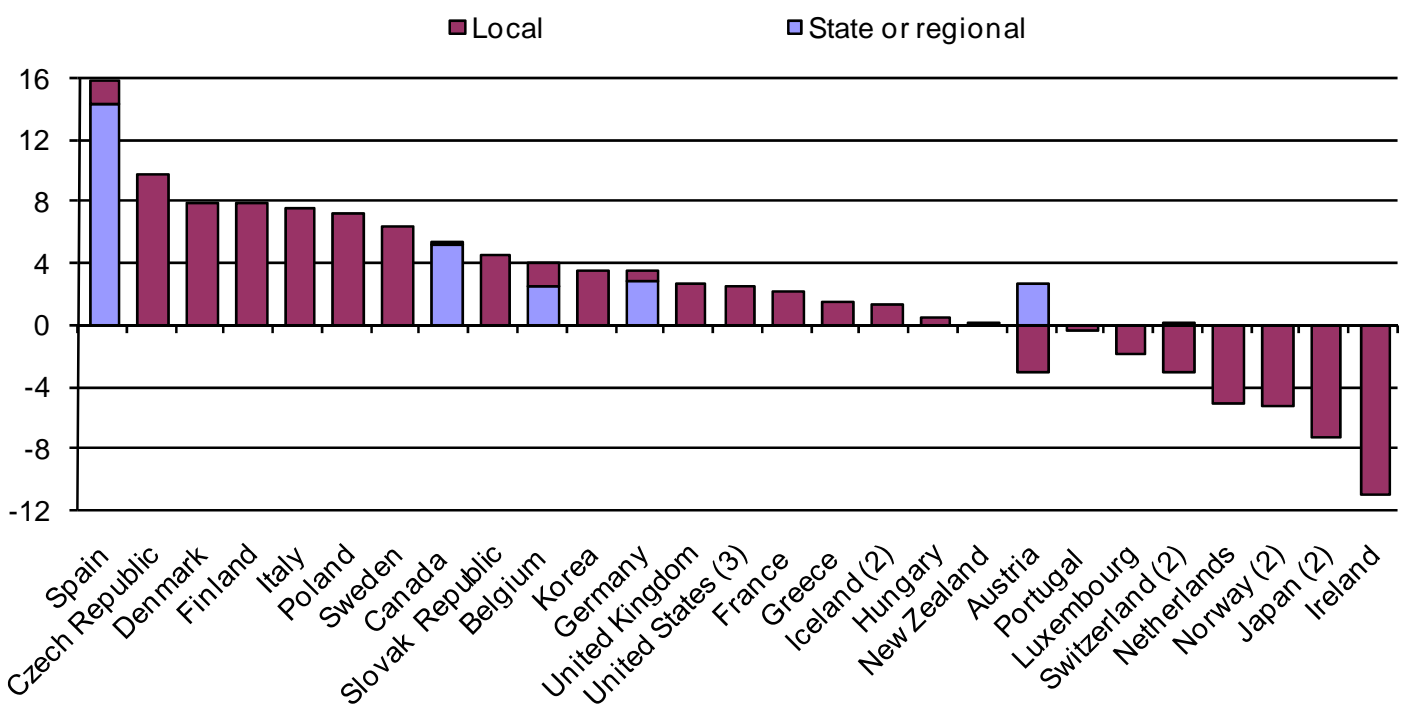

1. 2005 or latest year for which data are available. 2003 for New Zealand; 2004 for Japan, Korea and Switzerland.

2. Unconsolidated data.

3. No breakdown available for state and local government spending, all sub-level government spending included under local.

Sources: OECD National Accounts database; Statistics Canada; US Bureau of Economic Analysis. 
Figure 4. Share of sub-central government spending by main categories

2005 or earliest year available

Federal or regional countries

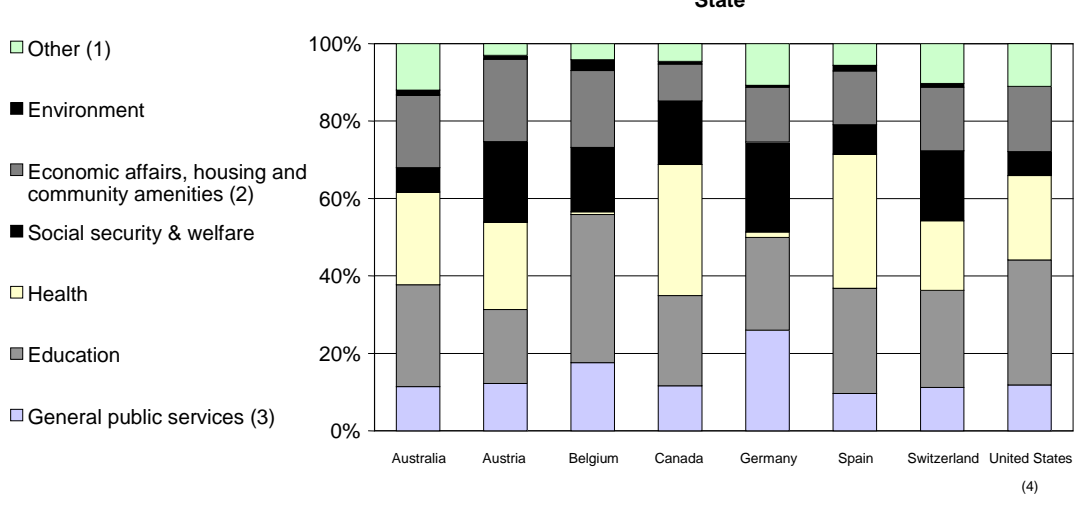

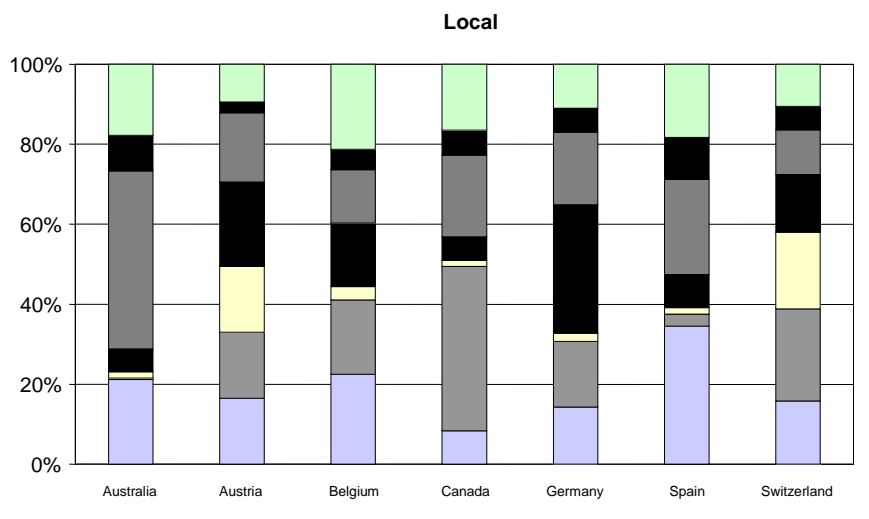

Unitary countries

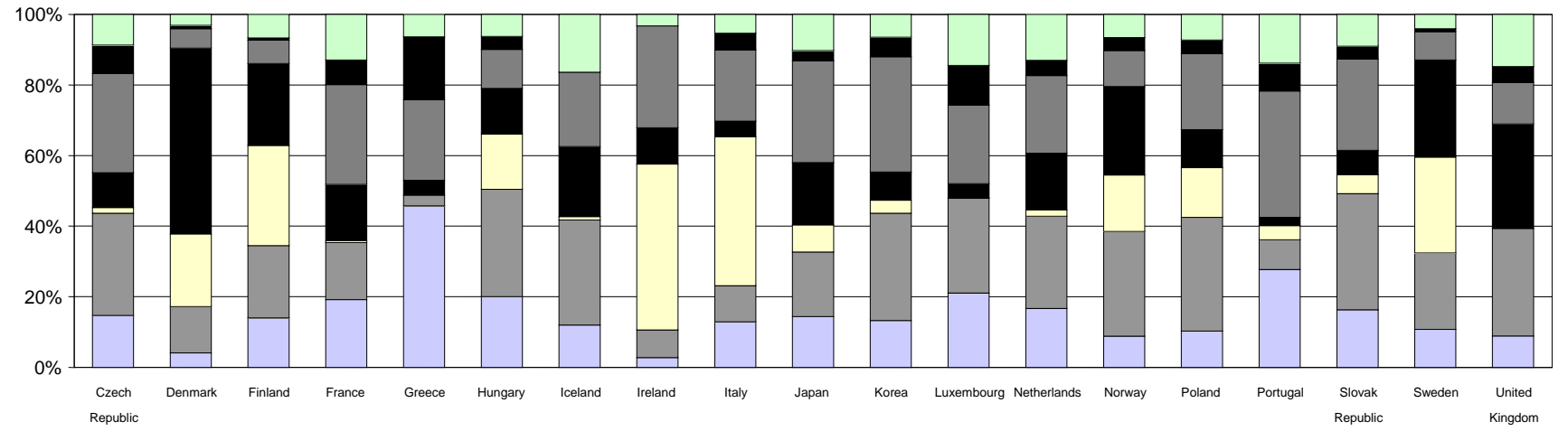

Other includes defence, environment protection, recreation, culture and religion.

industries; research and development economic affairs; economic affairs not else where classified.

4. For the United States, the National Accounts do not provide a breakdown between state and local governments

Sorce. OECD National Accounts except for Australia, Canada, Iceland, Japan and Switzerland; OECD estimates based on the White paper on local public finance published by the Ministry of Public 
Figure 5. Intermediate level indicator 1: Private ownership and contracting out

All public services

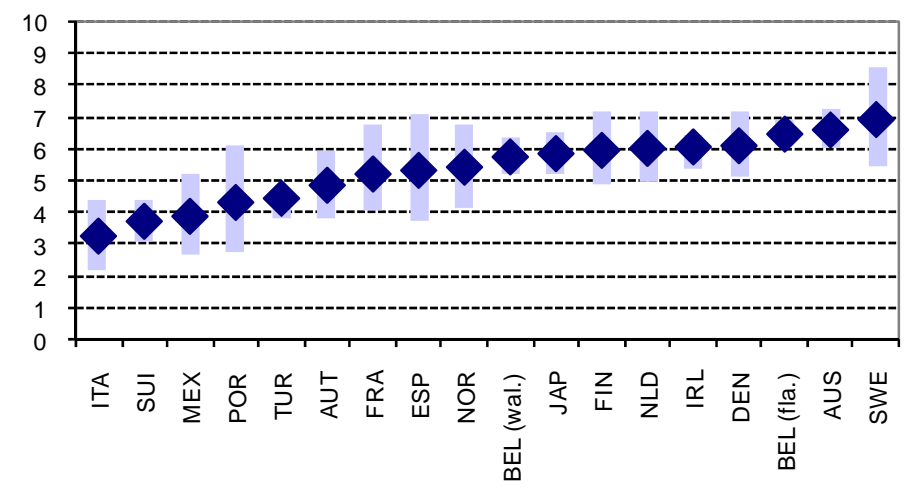

Figure 6. Intermediate level indicator 2: User choice and competition

All public services

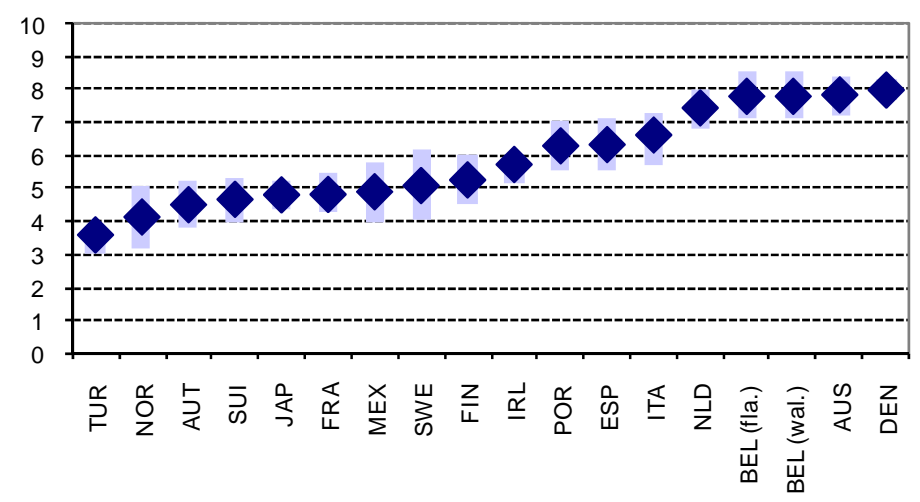

Note: Values scaled between 0 and 10 , with a higher value representing more efficient market arrangements in public service provision. For technical details on indicator construction, see Annex. 
Figure 7. User charges in OECD countries

a) Government revenue from sales of goods and services, per cent of GDP, 2005

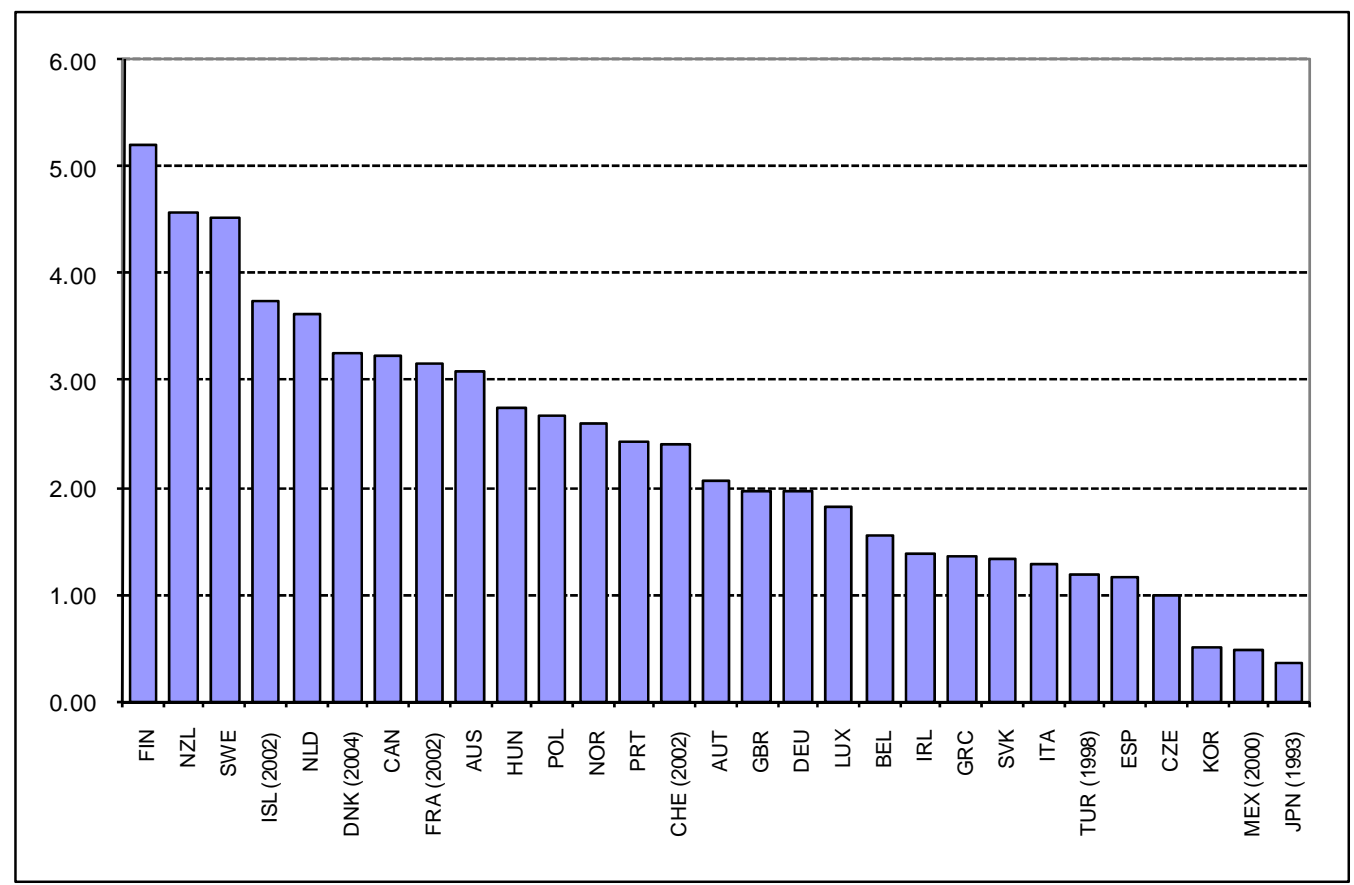

b) Government revenue from sales of goods and services, per cent of total government expenditure, 2005

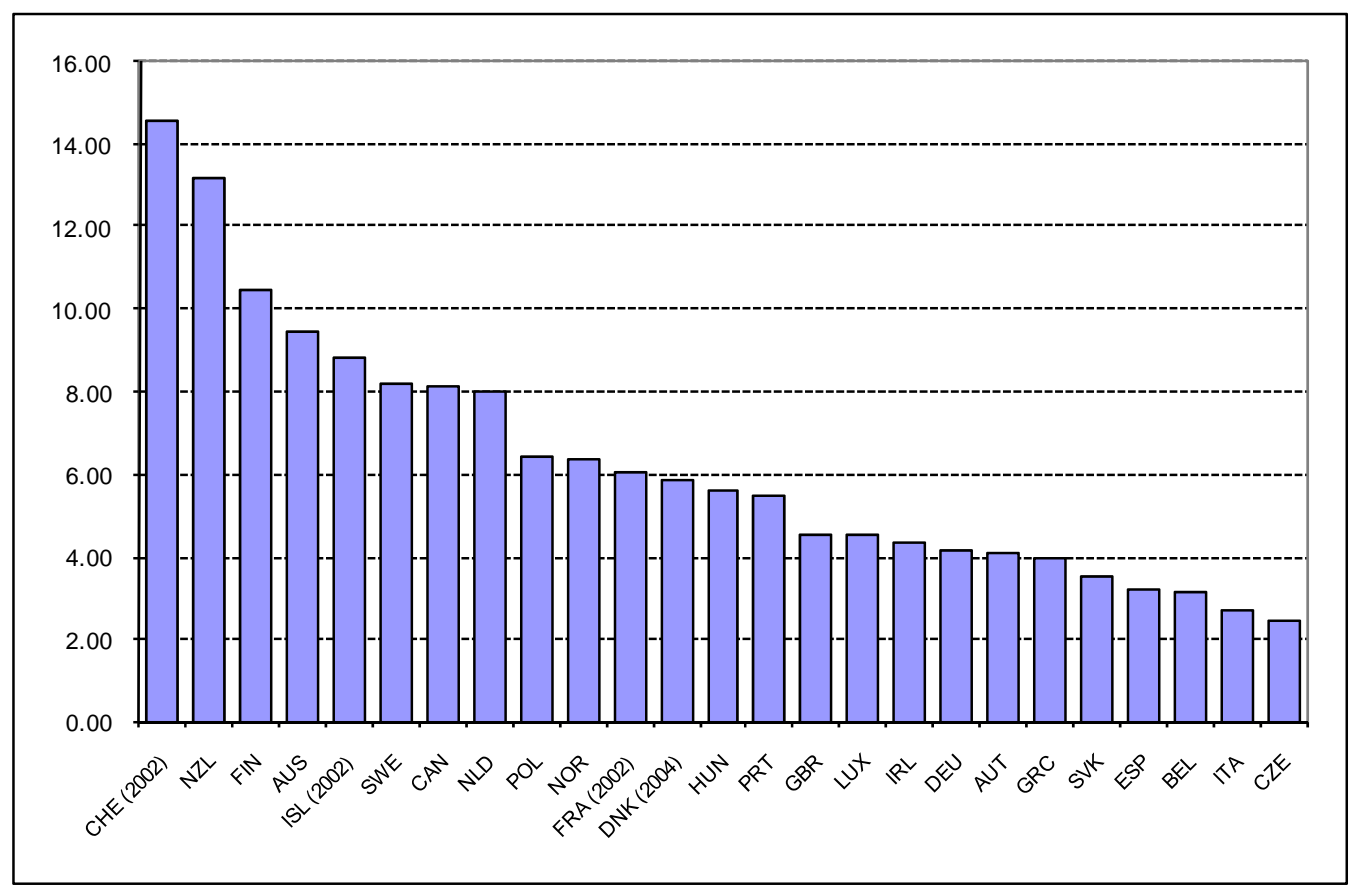


Figure 8. User charges across levels of government

a) Federal countries

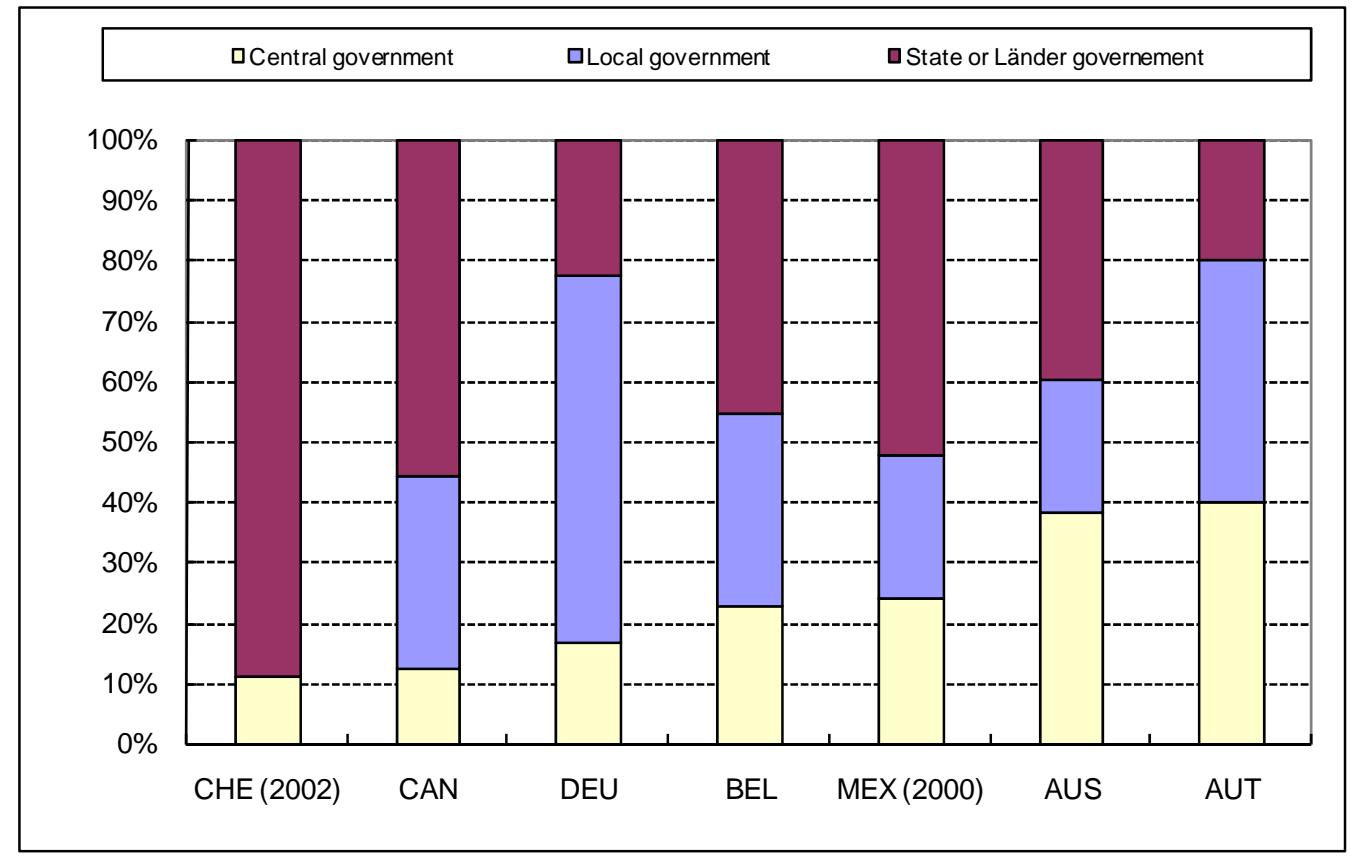

b) Unitary countries

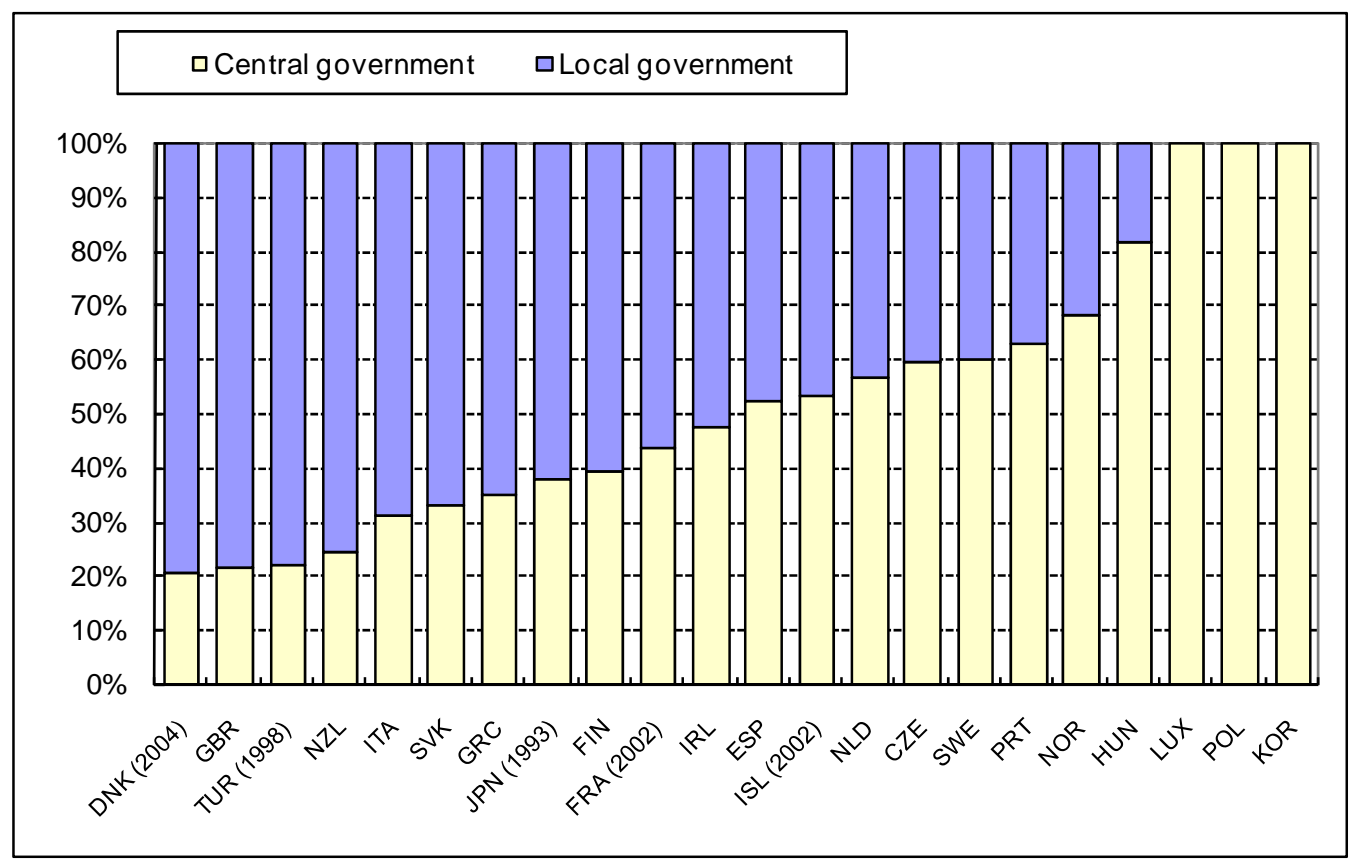

Note : Data for Japan, Korea, Mexico, Turkey and Switzerland are recorded on a cash basis and for Australia, Canada, Japan and New Zealand :data are on fiscal year basis. 
Figure 9. Intermediate level indicator 3: Price signals in funding

All public services

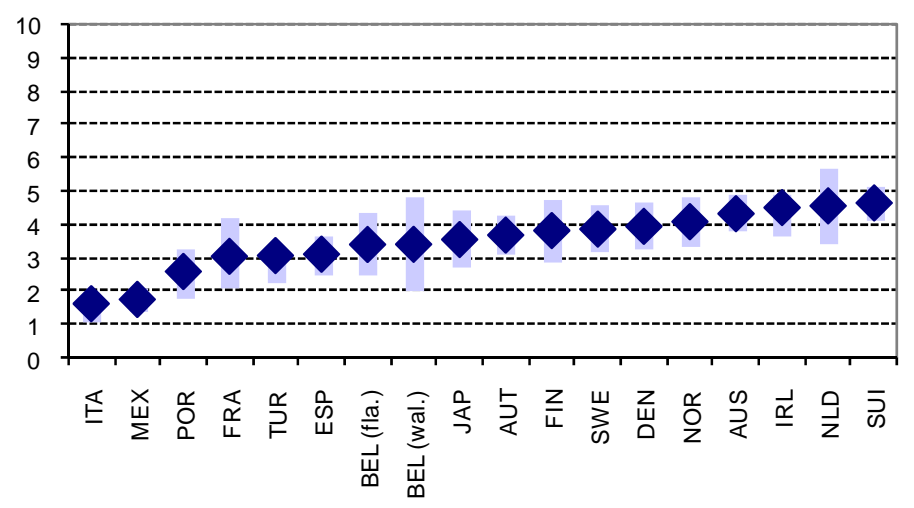

Note: Values scaled between 0 and 10, with a higher value representing more efficient market arrangements in public service provision. For technical details on indicator construction, see Annex. 
Figure 10. Summary indicator: use of market mechanisms in public service provision

a) Additive aggregation

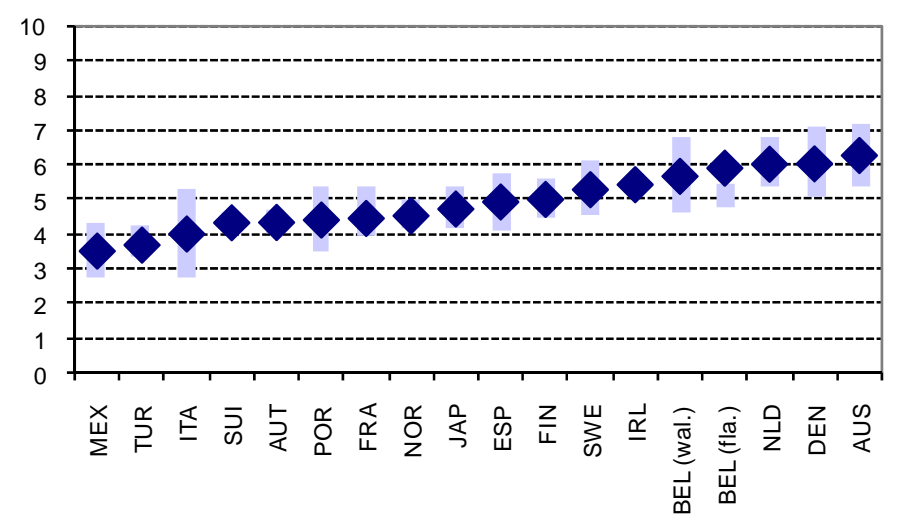

b) Multiplicative aggregation

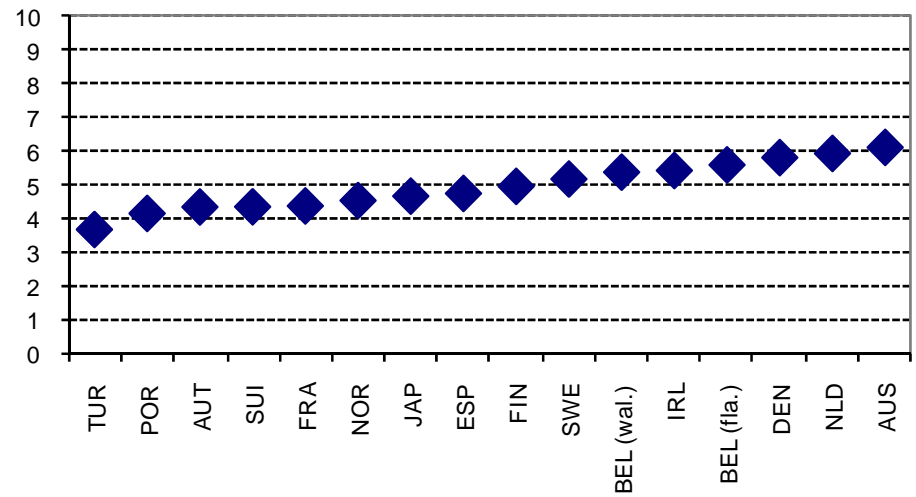

Note: Values scaled between 0 and 10, with a higher value representing more efficient market arrangements in public service provision. For technical details on indicator construction, see Annex. 


\section{COM/CTPA/ECO/GOV/WP(2008)6}

Figure 11. Policy reform gap for sub-central public services

a) Difference between actual implementation and recommendation, average

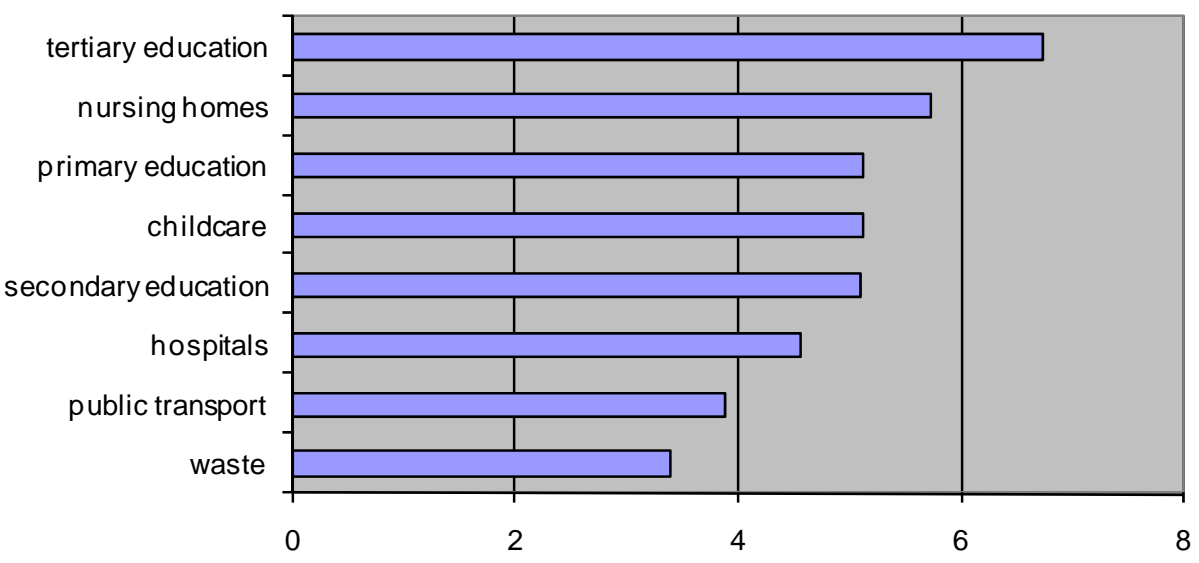

b) Difference between actual implementation and recommendation, sum

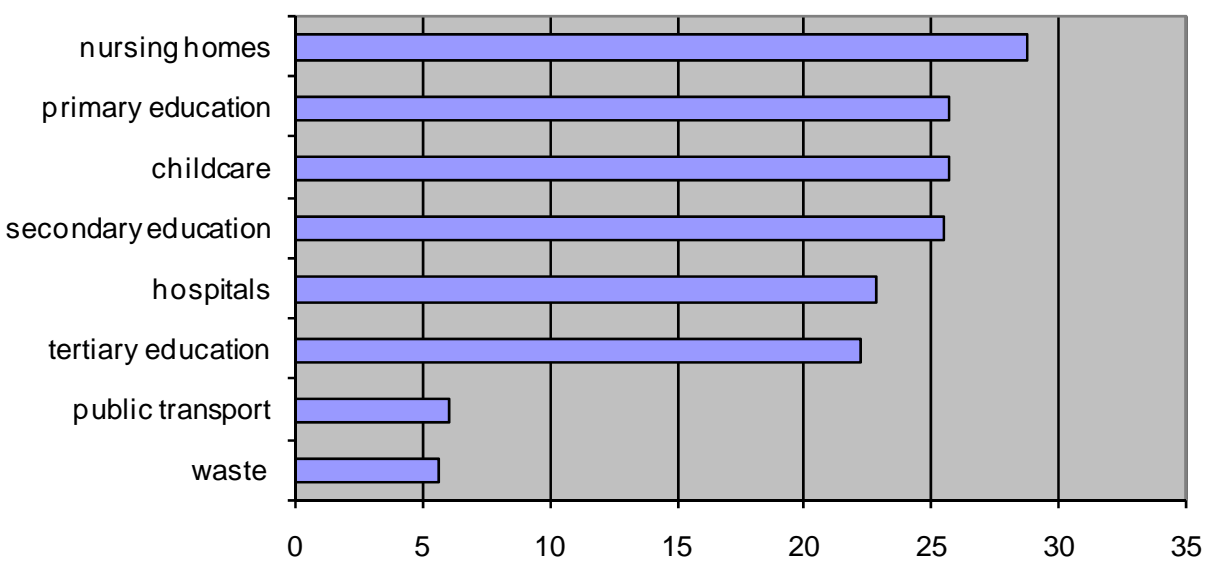

Note: The policy reform gap is the difference between actual implementation of market mechanisms and normative benchmarks derived from OECD recommendations, for each service. The longer the horizontal bar, the higher the policy gap or reform potential. For technical details see Annex. 


\section{ANNEX: CONSTRUCTING A SUMMARY INDICATOR OF MARKET MECHANISM RELIANCE}

51. The responses to the OECD questionnaire have been used to construct an indicator to assess to what extent and how efficiently SCGs rely on market mechanisms in public service provision. The individual country responses to the questionnaires are transformed into "low-level" indicators. These indicators are scaled on the interval 0 to 10 , with a higher score associated with a more efficient reliance on market mechanisms. The low-level indicators are used to construct intermediate indicators representing the three dimensions of market mechanism. The composite (or summary) indicator is constructed on the basis of the intermediate indicators, giving an overall picture of market mechanism efficiency in a single number.

\section{Data sources}

52. Most data were obtained through the questionnaire. In some cases complementary information was obtained from Delegates. Additional information was provided by the OECD education and health databases as well as activities of Working Party No. 1 of the Economic Policy Committee on institutional arrangements in education and health care (Gonand, Joumard and Price, 2007; Erlandsen, 2007).

\section{Coding}

53. Coding for the low-level indicators (LLI) is shown in Table A1. Each public service was coded separately, so a single LLI actually consists of eight (8) single values, representing the eight services for which data were required. Each service obtains the same weight when services are aggregated into a single LLI.

54. Some countries provided information for an incomplete set of public services only (e.g. if a service was not a sub-central responsibility). Table A2 shows which countries provided data for which service. Intermediate and summary indicators were adapted for these countries to account for the reduced data set, by taking into account the difference between averages for services obtained for that country and the average of all services. Data for France and Italy on primary and secondary education were provided by Gonand, Joumard and Price (2007).

55. Some countries provided data for both the local and the state/regional level. These data were aggregated into one level of sub-central government, by giving an equal weight to the local and the regional level.

56. Missing variables: Single missing variables were coded by taking the average for the respective LLI across countries. There are 1782 LLI data points altogether (99 services times 18 LLIs), out of which 104 are based on constructed variables.

\section{Aggregation}

57. Constructing an intermediate indicator through aggregation requires an assessment of the relative importance ascribed to LLIs. To help overcome the difficulties in assigning the relative importance of individual aspects of market mechanism in different institutional frameworks, the approach adopted here is to use random weights. This technique uses 1000 sets of randomly-generated weights for each LLI and then adds these weighted LLIs to obtain the ILI, so 1000 intermediate indicators for each sub-central level of government are calculated. The random weights are drawn from a uniform distribution between zero and one and then normalized so as to sum to one for all LLI forming the ILI. Accordingly, the resulting 
distribution of ILIs for each SCG reflects the possible range of values. The figures for intermediate and summary indicators hence show both indicator values and confidence intervals derived from these distributions (Sutherland, Price and Joumard, 2005).

58. For the construction of the summary indicator SI, two different approaches are applied. The first is to replicate the random weights technique and to add the weighted ILIs to obtain the summary indicator (see above). The second approach is multiplicative (or geometric) aggregation. This approach avoids some undesirable features of additive aggregation, namely that poor performance in one ILI can be compensated with high values in other ILIs. Multiplicative aggregation yields a higher summary indicator value if market mechanism arrangements are balanced, i.e. if ILI values do not differ too much across market mechanism dimensions. Formally:

$$
\begin{aligned}
& \text { Average aggregation: } S I_{j}=\frac{1}{3} \sum_{i=1}^{3} I L I_{i, j} \\
& \text { Multiplicative aggregation: } S I_{j}=\left(\prod_{k=1}^{3} I L I_{i, j}\right)^{\frac{1}{3}}
\end{aligned}
$$

where $S I_{j}$ stands for the summary indicator for country $\mathrm{j}$ and $I L I_{i, j}$ stands for the three randomlyweighted intermediate indicators for country j.

\section{Consistency of institutional arrangements}

59. Particular weight is given to consistency of market mechanism arrangements. The policy background for doing so is that market mechanisms introduced as a coordinated package rather than as isolated and/or uncoordinated measures are supposed to be more efficient. Consistency is accounted for in three ways. First, several LLIs indicators directly measure consistency, e.g. a setting whereby users are free to choose any provider and providers are free to enter the market gets a higher indicator value than user choice without market entry rights. Or a setting whereby the government level that sets a user fee structure is the same that gets the revenues yields a higher indicator value than a setting where decision and revenue collection are at different levels. Second, the summary indicator is obtained by applying both additive and multiplicative aggregation, whereby the latter gives a higher weight to a balanced distribution of intermediate indicator values (OECD 2005) ${ }^{20}$.

60. Third, confidence intervals based on the random weights technique for both intermediate and summary indicators can also be interpreted as a consistency measure. The higher the variation across lower-level indicator values, the larger becomes the confidence interval of an aggregated indicator. A low confidence interval can be interpreted as high consistency between the low level indicators; e.g. a system with an average number of private providers, average free market access, some tendering and outsourcing yields a smaller confidence interval than a system where some LLIs have very high values and others have very low values.

20. We do not assess consistency across services, assuming that low or inefficient implementation of market mechanisms in one service area (e.g. public transport) does not affect the efficiency outcome in another area (e.g. nursing homes). 


\section{Policy reform gap}

61. The policy reform gap is calculated using LLI values for each public service and confronting them with an "optimal" value that is derived from a set of OECD recommendations (see Table A3). The higher the difference between actual and potential value, the higher is the policy gap.

62. The policy reform gap is calculated in two alternative ways: as the average difference between the actual and potential LLIs, and as the sum of differences between actual and potential LLIs. The sum of differences approach better accounts for a varying number of policy reform proposals and hence a varying number of LLIs used to assess the policy reform gap, while the average differences approach levels out low and high policy reform gaps across LLIs. Formally:

$$
\begin{aligned}
& \text { Sum of differences: } P R G_{i}=10 m-\frac{1}{n} \sum_{k=1}^{m} \sum_{j=1}^{n} I_{i, j, k} \\
& \text { Average difference: } P R G_{i}=10-\left(\frac{1}{n m}\right) \sum_{k=1}^{m} \sum_{j=1}^{n} I_{i, j, k}
\end{aligned}
$$

where $P R G_{i}$ is the policy reform gap for service $\mathrm{i}, I_{i j k}$ is LLI k for service i in country j, m is the number of normative benchmarks (number of recommendations) and $\mathrm{n}$ is the number of countries for which data are available for that service. The number 10 is meant to be the optimal or "recommended" value, as shown in the coding table. The LLI selected for each service are shown in Table A3. 
COM/CTPA/ECO/GOV/WP(2008)6

Table A1. Coding for composite indicators

Use of market mechanism in sub-central public service provision

Low-level indicator

Weight

Coding

Private provision and contracting out

LLI-1 Private provision

(where $p(i)$ stands for the percentage of private providers

$\mathrm{p}(\mathrm{i}) / 10$

LLI-2 Outsourcing

At least one service is outsourced

Number of outsourced services (where e(i) stands for the number of outsourced services

if $e(i)<5$, else 10

$1 / 2$

\section{LLI-3 Tendering}

Free market access, no tendering

Open tendering and bidding

Restricted tendering and bidding

Negociation with pre-selected providers

LLI-4 Financial support for private providers

Government can fund private providers

LLI-5 Central government's role in supporting private provision

One or two positive measures (central government requires private property, central government uses financial incentives)

Central or state government has no influence on ownership

Central or state government prohibits private provision

User choice and competition among providers

LLI-6 User choice within a jurisdiction

User choice granted by the jurisdiction

Residents are free to use any provider within and outside the jurisdiction where they live

Residents are free to use any provider within their jurisdiction and may apply for a permission outside

Residents are free to use any provider within their jurisdiction but not outside

Residents need to apply for a permission to change a provider

Resdients have no freedom of choice and are assigned a provider

Restrictions on users from outside the jurisdiction

Users from outside the jurisdiction have free access

Users from outside the jurisdiction have free access but pay higher charges and fees

Users from outside the jurisdiction have no free access but may apply for permission

Users from outside the jurisdiction have no free access

$1 / 2$

LLI-7 User choice across jurisdictions

Residents have free choice both within and outside the jurisdiction and outside citizens have free acess

Residents may apply for permission to change a provider and outside citizens may apply for access

Residents have free choice within a jurisdiction and outside citizens may apply for access

Any other combination of user choice across jurisdictional borders

LLI-8 Market access for private providers

Market access

Free access to the market (including with concessions) 
LLI-9 Central government's role in granting user choice and market access

User choice

Central government entitles users to schoose freely

$2 / 3$

There is a horizontal agreement across jurisdictions to grant free choice

There is no central government rule

Central government prohibits free choice

Market access

Central government requires tendering

LLI-10 Consistency between market access and user choice

Q2a Users have free choice within and outside the jurisdiction and providers

have free access within and outside the jurisdiction

Users have free choice within the jurisdiction and providers

have free access within the jurisdiction

Any other arrangement of market access and user choice

Price signals in funding

\section{LLI-11 Scope of user fees}

Are user fees applied

(where $p(i)$ stands for the percentage of cost covered by user fees

LLI-12 Government level deciding on user fees

Who decides on level and structure of the fees?

$1 / 2$

Central government decides

Local government dedides

Shared decision-making

Provider decides

Where do revenues go?

Central government

Local government

Shared

Provider

$1 / 2$

\section{LLI-13 Consistency of user fee application}

Consistency between who decides and who gets the revenues

The body that decides on level and structure of fees is the same as the one that gets the revenues

The body that decides on level and structure of fees is not the same as the one that gets the revenues

Consistency between market structure and decision-making

If there is free market access, fees should be decided by the provider or if provision is tendered, then the local government should decide

Any other arrangement of market structure and decision making

LLI-14 User related funding ("vouchers")

Application of user-related government spending

There is some user-related funding

There is no user-related funding

Quality of user-related government spending

Funding is entirely activity-based (all funding is based on some use indicator)

Funding is strongly activity-based (between 50 and 100 percent of funding is based on some use indicator)

Funding is weakly activity-based (less than 50 percent of funding is based on some use indicator) 
Table 2A: Questionnaire responses

\begin{tabular}{|c|c|c|c|c|c|c|c|c|}
\hline & $\begin{array}{l}\text { Primary } \\
\text { education }\end{array}$ & $\begin{array}{l}\text { Secondary } \\
\text { education }\end{array}$ & $\begin{array}{l}\text { Tertiary } \\
\text { education }\end{array}$ & Hospitals & $\begin{array}{l}\text { Public } \\
\text { transport }\end{array}$ & $\begin{array}{c}\text { Nursing } \\
\text { homes }\end{array}$ & Childcare & $\begin{array}{l}\text { Waste } \\
\text { collection }\end{array}$ \\
\hline Australia & $x$ & $x$ & & $x$ & $x$ & $x$ & $x$ & $x$ \\
\hline Austria & $(x)$ & $(x)$ & & $x$ & $x$ & & & $x$ \\
\hline Belgium & $x$ & $x$ & $x$ & & & & $x$ & \\
\hline Canada & & & & & & & & \\
\hline Czech Republic & & & & & & & & \\
\hline Denmark & $x$ & $x$ & & $x$ & $x$ & $x$ & $x$ & $x$ \\
\hline Finland & $x$ & $x$ & $x$ & $x$ & $x$ & $x$ & $x$ & $x$ \\
\hline France & $(x)$ & $(x)$ & $x$ & $x$ & & & & \\
\hline Germany & & & & & & & & \\
\hline Greece & & & & & & & & \\
\hline Hungary & & & & & & & & \\
\hline Iceland & & & & & & & & \\
\hline Ireland & & & & $x$ & & $x$ & $x$ & $x$ \\
\hline Italy & $(x)$ & $(x)$ & & $x$ & $x$ & & & \\
\hline Japan & $x$ & $x$ & $x$ & $x$ & $x$ & & $x$ & $x$ \\
\hline Korea & & & & & & & & \\
\hline Luxemburg & & & & & & & & \\
\hline Mexico & $\mathrm{x}$ & $\mathrm{x}$ & $x$ & $\mathrm{x}$ & $x$ & $x$ & $x$ & $x$ \\
\hline Netherlands & $x$ & $\mathrm{x}$ & $x$ & $\mathrm{x}$ & $x$ & $x$ & $\mathrm{x}$ & $x$ \\
\hline New Zealand & & & & & & & & \\
\hline Norway & $\mathrm{x}$ & $x$ & & & $x$ & $x$ & $x$ & $x$ \\
\hline Poland & & & & & & & & \\
\hline Portugal & $x$ & $x$ & & $x$ & $x$ & $x$ & $x$ & $x$ \\
\hline Slovak Republic & & & & & & & & \\
\hline Spain & $x$ & $x$ & $x$ & $x$ & $x$ & $x$ & $x$ & $x$ \\
\hline Sweden & $x$ & $x$ & $x$ & $x$ & $x$ & $x$ & $x$ & \\
\hline Switzerland & $x$ & $x$ & $x$ & $x$ & $x$ & $x$ & $x$ & $x$ \\
\hline Turkey & $x$ & $x$ & & & $x$ & & & $x$ \\
\hline United Kingdom & & & & & & & & \\
\hline United States & & & & & & & & \\
\hline
\end{tabular}

Note: Information for services in brackets (x) were provided by Gonand, Joumard and Price (2007). 
Table A3: Low-level indicators used to construct the policy reform gap

Relevant Indicators

primary education LLI-4, LLI-6, LLI-7, LLI-14, LLI-15

secondary educati LLI-4, LLI-6, LLI-7, LLI-14, LLI-15

tertiary education LLI-11, LLI-12, LLI-13

hospitals LLI-6, LLI-7, LLI-8, LLI-14, LLI-15

public transport LLI-3, LLI-11, LLI-12

nursing homes LLI-6, LLI-7, LLI-11, LLI-12, LLI-13

childcare LLI-6, LLI-7, LLI-11, LLI-12, LLI-13)

waste LLI-3 
Table A4: Sub-central spending by function

\begin{tabular}{|c|c|c|c|c|c|c|c|c|c|c|c|c|c|c|c|c|}
\hline \multicolumn{17}{|c|}{$\begin{array}{l}\text { 'total subnational governments' } \\
2005 \text { or latest year available }\end{array}$} \\
\hline & \multicolumn{2}{|c|}{$\begin{array}{l}\text { General public } \\
\text { services }^{1}\end{array}$} & \multicolumn{2}{|c|}{ Education } & \multicolumn{2}{|c|}{ Health } & \multicolumn{2}{|c|}{$\begin{array}{l}\text { Social security \& } \\
\text { welfare }\end{array}$} & \multicolumn{2}{|c|}{$\begin{array}{c}\text { Housing \& } \\
\text { community } \\
\text { amenities }\end{array}$} & \multicolumn{2}{|c|}{ Economic affairs ${ }^{2}$} & \multicolumn{2}{|c|}{ Environment } & \multicolumn{2}{|c|}{ Other $^{3}$} \\
\hline & $\begin{array}{c}\text { State, } \\
\text { Region or } \\
\text { Province } \\
\end{array}$ & Local & $\begin{array}{c}\text { State, } \\
\text { Region or } \\
\text { Province } \\
\end{array}$ & Local & \begin{tabular}{|c|} 
State, \\
Region or \\
Province \\
\end{tabular} & Local & \begin{tabular}{|c|} 
State, \\
Region or \\
Province
\end{tabular} & Local & \begin{tabular}{|c|} 
State, \\
Region or \\
Province \\
\end{tabular} & Local & \begin{tabular}{|c|} 
State, \\
Region or \\
Province \\
\end{tabular} & Local & \begin{tabular}{|c|} 
State, \\
Region or \\
Province \\
\end{tabular} & Local & \begin{tabular}{|c|} 
State, \\
Region or \\
Province \\
\end{tabular} & Local \\
\hline \multicolumn{17}{|c|}{ Federal or regional countries } \\
\hline Australia (2004) & 11.4 & 21.2 & 26.3 & 0.3 & 23.9 & 1.6 & 6.3 & 5.7 & 3.4 & 15.3 & 15.4 & 29.2 & 1.3 & 9.0 & 12.0 & 17.8 \\
\hline Austria & 12.2 & 16.5 & 19.1 & 16.5 & 22.6 & 16.6 & 20.8 & 21.0 & 2.9 & 3.0 & 18.4 & 14.3 & 0.9 & 2.7 & 3.1 & 9.5 \\
\hline Belgium (2003) & 17.6 & 22.4 & 38.2 & 18.6 & 0.8 & 3.3 & 16.6 & 15.9 & 1.6 & 2.0 & 18.3 & 11.3 & 2.8 & 5.1 & 4.2 & 21.3 \\
\hline Canada (2004) & 11.6 & 8.3 & 23.3 & 41.2 & 33.8 & 1.4 & 16.5 & 5.9 & 1.2 & 7.6 & 8.3 & 12.8 & 0.7 & 6.2 & 4.6 & 16.5 \\
\hline Germany (2004) & 26.0 & 14.3 & 23.9 & 16.4 & 1.4 & 2.0 & 23.3 & 32.2 & 3.1 & 6.6 & 11.0 & 11.5 & 0.6 & 5.9 & 10.8 & 11.0 \\
\hline Spain (2004) & 9.7 & 34.4 & 27.2 & 3.1 & 34.7 & 1.6 & 7.6 & 8.3 & 1.8 & 12.5 & 12.0 & 11.3 & 1.5 & 10.5 & 5.6 & 18.3 \\
\hline Switzerland (2002) & 11.2 & 15.8 & 25.1 & 23.0 & 18.0 & 19.2 & 18.0 & 14.4 & 1.1 & 2.5 & 15.3 & 8.7 & 1.0 & 5.9 & 10.3 & 10.6 \\
\hline United States $^{4}$ & 11.8 & & 32.3 & & 21.8 & D & 6.2 & & 1.9 & .. & 14.8 & & 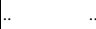 & + & 11.1 & \\
\hline Non-weighted average & 13.9 & 19.0 & 26.9 & 17.0 & 19.6 & 6.5 & 14.4 & 14.8 & 2.1 & 7.1 & 14.2 & 14.2 & 1.3 & 6.5 & 7.7 & 15.0 \\
\hline \multicolumn{17}{|l|}{ Unitary countries } \\
\hline Czech Republic & & 14.7 & & 29.0 & & 1.6 & & 9.9 & & 6.5 & & 21.6 & & 8.0 & & 8.7 \\
\hline Denmark & & 4.0 & & 13.1 & & 20.6 & & 52.7 & & 0.5 & & 5.0 & & 1.0 & & 3.1 \\
\hline Finland & & 14.0 & & 20.5 & & 28.4 & & 23.3 & & 0.4 & & 6.1 & & 0.7 & & 6.7 \\
\hline France & & 19.2 & & 16.2 & & 0.6 & & 15.8 & & 15.2 & & 13.1 & & 6.9 & & 13.0 \\
\hline Greece & & 45.7 & & 3.0 & & 0.0 & & 4.3 & & 8.3 & & 14.5 & & 17.8 & & 6.4 \\
\hline Hungary (2004) & & 20.0 & & 30.4 & & 15.8 & & 12.8 & & 6.5 & & 4.6 & & 3.7 & & 6.2 \\
\hline Iceland (2002) & & 12.0 & & 29.7 & & 1.0 & & 19.8 & & 6.3 & & 14.8 & & 0.0 & & 16.4 \\
\hline Ireland (2004) & & 2.7 & & 7.9 & & 47.0 & & 10.3 & & 13.4 & & 15.4 & & 0.0 & & 3.3 \\
\hline Italy (2004) & & 12.9 & & 10.2 & & 42.3 & & 4.4 & & 5.0 & & 15.2 & & 4.7 & & 5.3 \\
\hline Japan (FY2002) & & 14.4 & & 18.3 & & 7.7 & & 17.6 & & 2.2 & & 26.6 & & 2.9 & & 10.3 \\
\hline Korea (2004) & & 13.2 & & 30.4 & & 3.7 & & 8.0 & & 10.0 & & 22.6 & & 5.5 & & 6.5 \\
\hline Luxembourg & & 21.1 & & 26.8 & & 0.2 & & 4.0 & & 7.1 & & 15.1 & & 11.3 & & 14.4 \\
\hline Netherlands ${ }^{5}(2004)$ & & 16.7 & & 26.1 & & 1.8 & & 16.1 & & 6.5 & & 15.5 & & 4.3 & & 13.1 \\
\hline Norway & & 8.8 & & 29.7 & & 16.0 & & 25.1 & & 4.4 & & 5.8 & & 3.7 & & 6.6 \\
\hline Poland (2004) & & 10.3 & & 32.2 & & 14.0 & & 10.8 & & 9.0 & & 12.4 & & 3.9 & & 7.3 \\
\hline Portugal & & 27.7 & & 8.4 & & 4.0 & & 2.4 & & 12.5 & & 23.3 & & 7.8 & & 13.9 \\
\hline Slovak Republic (2004) & & 16.3 & & 32.9 & & 5.4 & & 6.9 & & 12.2 & & 13.7 & & 3.6 & & 9.1 \\
\hline Sweden (2004) & & 10.8 & & 21.6 & & 27.1 & & 27.6 & & 2.8 & & 5.3 & & 0.8 & & 4.1 \\
\hline United Kingdom (2004) & & 8.9 & & 30.5 & & 0.0 & & 29.6 & & 3.3 & & 8.5 & & 4.5 & & 14.8 \\
\hline Non-weighted average & & 16.4 & & 23.5 & & 8.7 & & 16.8 & & 6.7 & & 13.4 & & 5.1 & & 9.4 \\
\hline
\end{tabular}

1. General public services include public debt transactions.

2. Economic affairs covers general economic, commercial and labour affairs; agriculture, forestry, fishing and hunting; fuel and energy, mining, manufacturing and construction; transport; communication; other industries; research and development economic affairs; economic affairs not else where classified.

3. Other includes defence, public order and safety, recreation, culture and religion.

4. For the United States, National Accounts do not provide a breakdown between state and local governments.

Source: OECD National Accounts except for Australia, Canada, the Czech Republic, Hungary, Iceland, Ireland, Poland, the Slovak Republic, Switzerland; OECD estimates based on the White paper on local public finance published by the Ministry of Public Management, Home Affairs, Posts and Telecommunications for Japan; IMF, Government Finance Statistics Yearbook for the others. 
TABLE 5A: LOW-LEVEL AND INTERMEDIATE-LEVEL INDICATOR SCORES

\begin{tabular}{|c|c|c|c|c|c|c|c|c|c|c|c|c|c|c|c|c|c|c|c|c|c|}
\hline & LLI-1 & LLI-2 & LLI-3 & LLI-4 & LLI-5 & LLI-6 & LLI-7 & LLI-8 & LLI-9 & LLI-10 & LLI-11 & LLI-12 & LLI-13 & LLI-14 & LLI-15 & LLI-16 & LLI-17 & $\mathrm{II}-1$ & H-2 & II-3 & II-4 \\
\hline Australia & 6.83 & 7.29 & 5.36 & 10.00 & 5.00 & 8.57 & 7.14 & 6.43 & 6.43 & 10.00 & 4.27 & 3.39 & 2.86 & 6.19 & 4.64 & 5.15 & 4.29 & 6.90 & 7.71 & 4.27 & 5.99 \\
\hline Austria & 1.82 & 6.60 & 3.00 & 8.00 & 5.00 & 5.38 & 4.66 & 4.00 & 6.50 & 2.00 & 4.25 & 3.50 & 2.00 & 5.67 & 3.00 & 2.83 & 1.50 & 4.88 & 4.51 & 3.68 & 4.09 \\
\hline Belgium (fla.) & 6.45 & 7.25 & 6.25 & 7.50 & 5.00 & 9.06 & 7.50 & 6.25 & 6.25 & 10.00 & 3.13 & 4.38 & 1.25 & 6.67 & 1.56 & 1.32 & 0.00 & 6.49 & 7.81 & 3.40 & 5.60 \\
\hline $\begin{array}{l}\text { Belgium (wal.) } \\
\text { Canada }\end{array}$ & 4.38 & 7.00 & 5.00 & 7.50 & 5.00 & 9.06 & 7.50 & 6.25 & 6.25 & 10.00 & 2.98 & 3.75 & 0.00 & 8.75 & 1.50 & 1.32 & 0.00 & 5.78 & 7.81 & 3.39 & 5.60 \\
\hline Finland & 2.99 & 9.17 & 5.94 & 8.13 & 3.75 & 5.47 & 4.90 & 5.94 & 7.50 & 2.50 & 4.08 & 3.75 & 0.00 & 6.25 & 5.08 & 2.11 & 5.16 & 5.99 & 5.26 & 3.83 & 4.55 \\
\hline France & 1.50 & 7.96 & 3.75 & 7.50 & 3.75 & 5.63 & 5.00 & 5.00 & 5.00 & 2.50 & 2.78 & 2.81 & 0.00 & 6.25 & 2.36 & 1.60 & 3.13 & 4.89 & 4.63 & 2.84 & 3.73 \\
\hline $\begin{array}{l}\text { Germany } \\
\text { Greece } \\
\text { Hungary } \\
\text { Iceland }\end{array}$ & & & & & & & & & & & & & & & & & & & & & \\
\hline Ireland & 5.83 & 7.53 & 8.13 & 7.50 & 3.75 & 7.81 & 5.63 & 7.50 & 5.00 & 5.00 & 7.55 & 6.00 & 3.75 & 2.08 & 5.43 & 2.01 & 4.06 & 6.55 & 6.19 & 4.96 & 5.57 \\
\hline Japan & 4.89 & 4.57 & 6.25 & 8.57 & 5.14 & 5.36 & 4.76 & 5.36 & 5.71 & 2.86 & 5.63 & 5.89 & 2.14 & 2.62 & 1.43 & 1.90 & 3.39 & 5.89 & 4.81 & 3.54 & 4.18 \\
\hline $\begin{array}{l}\text { Korea } \\
\text { Luxemburg }\end{array}$ & & & & & & & & & & & & & & & & & & & & & \\
\hline Mexico & 2.04 & 5.00 & 8.44 & 0.00 & 4.38 & 4.22 & 3.44 & 7.50 & 6.88 & 2.50 & 3.13 & 2.03 & 0.63 & 1.25 & 1.81 & 2.88 & 5.47 & 3.97 & 4.91 & 1.77 & 3.34 \\
\hline $\begin{array}{l}\text { Netherlands } \\
\text { New Zealand }\end{array}$ & 6.46 & 4.38 & 8.13 & 8.75 & 2.50 & 7.97 & 5.00 & 8.13 & 7.50 & 8.75 & 5.73 & 2.38 & 1.88 & 8.38 & 4.33 & 3.70 & 2.84 & 6.04 & 7.47 & 4.54 & 6.00 \\
\hline $\begin{array}{l}\text { Norway } \\
\text { Poland }\end{array}$ & 2.18 & 7.00 & 8.75 & 8.33 & 2.50 & 3.85 & 3.19 & 7.50 & 5.00 & 1.67 & 4.93 & 3.75 & 0.83 & 5.28 & 5.80 & 1.43 & 0.00 & 5.75 & 4.24 & 4.12 & 4.18 \\
\hline $\begin{array}{l}\text { Portugal } \\
\text { Slovak Republic }\end{array}$ & 1.63 & 3.29 & 11.43 & 4.29 & 1.43 & 5.54 & 5.24 & 7.86 & 8.57 & 4.29 & 4.46 & 2.86 & 0.00 & 3.81 & 1.79 & 4.72 & 4.82 & 4.41 & 6.30 & 2.58 & 4.44 \\
\hline Spain & 2.13 & 7.25 & 8.44 & 7.50 & 0.31 & 6.56 & 4.58 & 8.75 & 4.38 & 7.50 & 3.19 & 3.75 & 0.63 & 4.92 & 3.68 & 3.99 & 2.50 & 5.13 & 6.35 & 3.23 & 4.79 \\
\hline Sweden & 2.17 & 9.57 & 8.93 & 10.00 & 4.29 & 6.25 & 2.86 & 8.57 & 5.00 & 2.86 & 3.41 & 3.57 & 1.43 & 5.71 & 5.26 & 1.35 & 4.64 & 6.99 & 5.11 & 3.88 & 4.49 \\
\hline Switzerland & 2.35 & 1.80 & 4.69 & 5.00 & 5.00 & 5.31 & 2.50 & 6.25 & 5.63 & 3.75 & 5.84 & 5.47 & 3.13 & 5.21 & 3.58 & 3.16 & 2.03 & 3.77 & 4.69 & 4.64 & 4.67 \\
\hline Turkey & 2.70 & 5.25 & 6.25 & 2.50 & 5.00 & 3.75 & 5.83 & 2.50 & 2.50 & 2.50 & 3.34 & 2.50 & 5.00 & 0.00 & 3.75 & 0.00 & 0.00 & 4.34 & 3.42 & 2.92 & 3.17 \\
\hline
\end{tabular}

